\title{
DIGITALCOMMONS
}

—@WAYNESTATE-

Wayne State University

$1-1-2011$

\section{Pushing the Limits of Global Governance: Trading Rights, Censorship and WTO Jurisprudence -- A Commentary on the China-Publications Case}

Julia Ya Qin

Wayne State University

\section{Recommended Citation}

Qin, Julia Ya. Pushing the Limits of Global Governance: Trading Rights, Censorship and WTO Jurisprudence -- A Commentary on the China-Publications Case. 10 Chinese J. Int'1 L. 271 (2011)

Available at: https://digitalcommons.wayne.edu/lawfrp/256 


\title{
Pushing the Limits of Global Governance: Trading Rights, Censorship and WTO Jurisprudence-A Commentary on the China-Publications Case
}

\author{
Julia Ya Qin*
}

\begin{abstract}
For decades, China has maintained State import monopoly in cultural products. The opaque State trading operations ensure a maximum level of flexibility and efficacy in the government censorship of imports. The WTO judiciary held in the China-Publications case that this practice is inconsistent with China's trading rights commitments under its Accession Protocol and cannot be justified by the public morals exception of the General Agreement on Tariffs and Trade. To comply with the WTO ruling, China must restructure its censorship regime, which it apparently is not prepared to do. This article analyses the implications of the WTO decision and provides a critical assessment of the new WTO jurisprudence regarding trading rights and the China Accession Protocol.
\end{abstract}

1. On 19 January 2010, the Dispure Setrlement Body (DSB) of the World Trade Organization adopted the Appellate Body (AB) report in China-Measures Affecting Trading Rights and Distribution Services for Certain Publications and Audiovisual

* Professor of Law, Wayne State University Law School, USA (email: ya.qin@wayne.edu). I wish to thank Erica Beecher-Monas, Sungjoon Cho, Donald Clarke, Milan Hejtmanek, Hilary Josephs, Amelia Porges, Ruosi Zhang and the anonymous reviewers for their helpful comments; Michael Hickman, Xiaojie Lu, and a number of other persons who wish to remain anonymous, for sharing insights with me during my research; and Aaron Silvenis for research assistance. The date of completion for this article is 10 April 2011 and all websites cited are current as of this date. 
Entertainment Products (China-Publications), ${ }^{1}$ and the Panel report ${ }^{2}$ as modified by the $\mathrm{AB}$ report. ${ }^{3}$ The $\mathrm{AB}$ and Panel found that China violated WTO law by not allowing non-State-owned entities to engage in the importation of cultural products (including books, magazines, newspapers, electronic publications, DVDs, sound recordings and films) and by prohibiting foreign entities from engaging in the distribution services for cultural products inside China. More specifically, the WTO judiciary held that China's restrictions on the right to import are inconsistent with its commitments to liberalize trading rights under its Accession Protocol, ${ }^{4}$ and that its restrictions on distribution services are inconsistent with its obligations under the General Agreement on Trade in Services (GATS) and the General Agreement on Tariffs and Trade (GATT). Most significantly, the WTO judges rejected China's defence that its restrictions on trading rights are necessary for the conduct of censorship and can therefore be justified by the "public morals" exception of the GATT.

2. China was given 14 months, or until 19 March 2011, to comply with the WTO rulings. At the time of writing, China has issued and proposed several amendments to its regulations concerning the right to import cultural products. But these amendments have all fallen short of meeting the WTO requirements.

3. China's failure to fully implement the WTO ruling, however, is not surprising. For decades, China has imposed ownership restrictions on its cultural industry, a sector deemed most politically sensitive to the Communist Party. Although ownership restrictions have been gradually relaxed in recent years, certain activities still remain off-limits to private enterprises, including the importation of cultural products. Under this system, only selected State-owned entities (SOEs) are authorized to import cultural and information products, and they are entrusted with the task of conducting censorship in the process. Such exclusive State trading ensures direct government control over the inflow of foreign contents. More critically, it allows the government to keep its censorship process non-transparent, which provides the system with the maximum level of flexibility and efficacy desired.

4. Thus, to comply with the WTO ruling would require the Chinese government to embark on serious systemic reforms. It would have to dismantle the decades-old State import monopoly and allow all domestic and foreign private entities to engage in the importation of sensitive products. And to do so, it would have to restructure its censorship regime and forgo State trading as its preferred means of political

1 WT/DS363/AB/R (21 December 2009) (hereinafter, "AB Report").

2 Panel Report, China-Measures Affecting Trading Rights and Distribution Services for Certain Publications and Audiovisual Entertainment Products, WT/DS363/R (12 August 2009) (hereinafter, "Panel Report").

3 WT/DS363/14 (21 January 2010).

4 Protocol on the Accession of the People's Republic of China, WT/L/432 (10 November 2001) (hereinafter, "Accession Protocol" or "Protocol"). 
control over content imports. Such systemic reforms could not occur without support from the leadership of the Communist Party. That support, however, seems unlikely in the current political environment.

5. In requiring China to undertake these systemic reforms, the WTO judiciary has pushed global governance ${ }^{5}$ to a new level-never before has any international organization or tribunal mandated changes of such political nature in the domesric system of a sovereign nation. This far-reaching decision, however, is not accidental. It is consistent with the trend of expansion in WTO governance. Traditionally, the world trading system was concerned solely with economic protectionism when domestic regulations were at issue. Accordingly, domestic measures restricting trade were permitted so long as they were not discriminatory against imported products or otherwise taken for protectionist purposes. With the establishment of the WTO, the system has expanded to cover many areas that were traditionally under the domestic regulatory domain, such as intellectual property rights, health and safety standards, investment policies and domestic subsidies. New rules in these areas have empowered the WTO judiciary to engage in more intrusive review of domestic regulations and to invalidate national measures for being inconsistent with international standards regardless of whether they are protectionist in design. The WTO jurisdiction has been further expanded through its accession regime. Countries applying to join the system after the Cold War have been typically required to take on additional ("WTO-plus") obligations with respect to their domestic policies and regulatory system. ${ }^{6}$ Liberalizing trading rights is one such obligation. China-Publications is the first case involving a major WTO-plus obligation. ${ }^{7}$ The $\mathrm{AB}$ and Panel construed this obligation strictly, and the result is a resounding confirmation of the expansive reach of the WTO.

5 The term "global governance" refers to the sum of laws, norms, policies and institutions that define, constitute and mediate relations among citizens, society, markets and the State in the international arena. Thomas G. Weiss and Ramesh Thakur, Global Governance and the UN: An Unfinished Journey (Indiana University Press, 2010), 6. "The prevailing state of affairs in global governance at any given time is shaped by an ever-present tension between the need to internationalize rules and the desire to assert and retain national control." John Gerard Ruggie, "Foreword", in: Weiss and Thakur, id., xv.

6 The scope and types of WTO-plus provisions vary from country to country, with those for China being most extensive and far-reaching. For summary of the special commitments of acceding members, see WTO Secretariat, Technical Note on the Accession Process, WT/ ACC/10/Rev.4/Add.1 (25 May 2010). See also Steve Charnovitz, Mapping the Law of WTO Accession, in: Merit E. Janow, Victoria Donaldson and Alan Yanovich (eds.), The WTO: Governance, Dispute Settlement and Developing Countries (Juris Publishing, 2008), ch. 46; Julia Ya Qin, "WTO-Plus" Obligations and Their Implications for the WTO Legal System - An Appraisal of the China Accession Protocol, 37 Journal of World Trade (2003), 483.

7 For disputes involving other WTO-plus obligations, see Julia Ya Qin, The Challenge of Interpreting "WTO-Plus" Provisions, 44 Journal of World Trade (2010), 127. 
6. Focusing on the trading rights portion of the WTO decision, ${ }^{8}$ this Commentary aims to make two contributions. Firstly, it seeks to explain the implications of the WTO decision for China's domestic system. Such implications tend to be underestimated by outside observers. ${ }^{9}$ Secondly, it provides a critical assessment of the new jurisprudence on trading rights and China's Accession Protocol. It contends that while the $\mathrm{AB}$ has broken new ground in integrating Member-specific accession obligations with the generally applicable WTO rules, its legal reasoning contains serious flaws. These flaws seriously impair the quality of its decision, casting doubts on the soundness of the final outcome. The interpretive problems exposed in this case demonstrate the special challenge of interpreting Memberspecific obligations within the WTO multilateral framework. But they are ultimately attributable to the narrow textualist approach taken by the WTO judiciary.

7. The rest of the article will proceed as follows. Section I provides the background of China's trading rights obligations, a summary of the Panel and $A B$ decisions and the status of China's compliance. Section II analyses the implications of the WTO ruling for China's domestic system, focusing on its censorship regime, economic reform and foreign trade. Section III evaluates the new jurisprudence concerning trading rights and the Accession Protocol and identifies the sources of the interpretive problems exposed in the WTO decision. Section IV sets forth the conclusion.

\section{An Overview}

\section{I.A. Trading rights and political censorship: a general background}

8. China acceded to the WTO in December 2001. As part of its accession commitments, China agreed that, within three years after accession, "all enterprises in China", and "all foreign individuals and enterprises, including those not invested or registered in China", would have the right to import and export all goods throughout its customs territory, except for a list of products reserved for trading by designated SOEs. ${ }^{10}$ The list of products reserved for State trading is set out in

8 The issue of censorship was raised only in the context of trading rights. It is unclear why China did not invoke the public morals exception under the GATS to defend its restrictions on distribution rights.

9 For previous commentaries on this case, see Joost Pauwelyn, Squaring Free Trade in Culture with Chinese Censorship: The WTO Appellate Body Report in China-Audiovisuals, 11 Melbourne JIL (2008), 1; Xiaohui Wu, Case Note: China-Measures Affecting Trading Rights and Distribution Services for Certain Publications and Audiovisual Entertainment Products (WT/DS363/AB/R), 9 Chinese JIL (2010), 415; Jingxia Shi and Weidong Chen, The "Specificity" of Cultural Products v. the "Generality" of Trade Obligations: Reflecting on China-Publications and Audiovisual Products, 45 Journal of World Trade (2011), 159.

10 Protocol, paras.5.1 and 5.2; Report of the Working Party on the Accession of China, WT/ MIN(01)/3 (10 November 2001) (hereinafter, "Working Party Report", or "WPR"), paras. 83 and 84 , which were incorporated into the Protocol. The right of all foreign individuals and enterprises to trade is granted under the national treatment clause of paragraph 5.2 
Annex $2 \mathrm{~A}$ of the Accession Protocol, which includes 84 products for importation and 134 products for exportation. The 84 products subject to State trading for importation fall under the categories of grain, vegetable oil, sugar, tobacco, processed oil, chemical fertilizer and cotton. No cultural or information product is mentioned in Annex 2A.

9. China's commitment to liberalize trading rights was a critical step in the reform of its foreign trade regime. Prior to the mid-1980s, all foreign trade in China was conducted by State trading firms. In the next 20 years, the State trading system was considerably liberalized. By the time of China's accession, numerous domestic and foreign entities had obtained the right to engage in imports and exports directly. Nonetheless, the government still controlled the allocation of trading rights through an entity-by-entity approval system. This system was put to an end in 2004 when China implemented its trading rights commitments to the WTO. Under the revised Foreign Trade Law, operating import and export businesses in China no longer requires government approval; instead, any person wishing to engage in foreign trade may do so simply by completing a registration procedure with the Ministry of Commerce. ${ }^{11}$ The implementation of the WTO commitments, therefore, has fundamentally changed the way China conducts its foreign trade.

10. Despite the fact that cultural and information products are not among those specifically reserved for State trading under the Accession Protocol, China has never liberalized the right to import these products. On the contrary, following the amendment of the Foreign Trade Law, the government reiterated its policy of prohibiting non-State capital from engaging in the importation of cultural products. ${ }^{12}$ This prohibition is part of a long-standing policy that the Chinese government has maintained in the media and cultural industries. Although China's media and cultural sectors have become increasingly commercialized over time, ${ }^{13}$ the government

of the Protocol. Paragraph 84 of the WPR further provides that China would "eliminate its system of examination and approval of trading rights within three years after accession" and that such rights would be "granted in a non-discriminatory and non-discretionary way."

11 Documents required for registration are mostly for identification purposes. The Ministry of Commerce must complete the registration within five days of receipt of the required documents. Foreign Trade Law of the People's Republic of China, as amended, effective 1 July 2004, arts. 8 and 9.

12 See, e.g., The Catalogue for Guidance of Foreign Investment Industries, Order [2004] No. 24 of the State Development and Reform Commission, the Ministry of Commerce (30 November 2004) ("Industry Catalogue"); The Several Opinions of the Ministry of Culture, State Administration of Radio, Film and Television, General Administration of Press and Publication, National Development and Reform Commission and the Ministry of Commerce on Introducing Foreign Investment into the Cultural Sector, Order [2005] No. 19 of the Ministry of Culture (6 July 2005).

13 Except for a few media outlets directly controlled by the Party, Chinese media enterprises must finance themselves mostly through subscriptions and adverrisement. See Benjamin 
has maintained firm control over these sensitive domains. Such control is exercised through censorship of press, media and the Internet, which is carried out to a large extent by maintaining dominant State ownership in these industries. Thus, under Chinese law, private capital is prohibited from owning or operating news agencies, publishing houses, radio or TV stations, and from engaging in the import of cultural products. ${ }^{14}$ Foreign investment in the media and cultural sectors is strictly limited, ${ }^{15}$ because the Party is particularly concerned with foreign influences that it deems as conveying ideas that could impair or subvert its rule. ${ }^{16}$

11. The relationship between State ownership and censorship needs to be understood in the light of the way in which content is regulated in China. Formally under Chinese law, censorship criteria are formulated in very broad and vague terms. Prohibited content, for example, includes any materials that "defy the basic principles of the Constitution", "injure the national glory and interests", "incite hatred or discrimination" or "infringe upon customs and habits of the nationalities", "propagate evil cults or superstition" or "disturb public order or destroys social stability". 17 Consequently, whether a particular item is deemed to be within a prohibited category depends on interpretation. In practice, China's content-control system relies on a combination of internal instructions from the Party's propaganda authorities, a system of publisher and editor responsibility for content (self-censorship) and post-publication sanctions for those who violate explicit or implicit limits. ${ }^{18}$ Although pre-publication review of content is sometimes required, it is generally not key to overall Party management of the media. ${ }^{19}$ Editors who breach Party norms or who misjudge the prevailing political winds risk loss of their positions or suffer more severe punishment. ${ }^{20}$

12. This exceedingly opaque system allows the Party to adjust its censorship criteria constantly according to the perceived danger of the day, and it works best with

Liebman, Watchdog or Demagogue? The Media in the Chinese Legal System, 105 Columbia LR (2005), 1, 23-28. See also, Sigrun Abels, State vs. Market: Media in Transition, International Institute for Asian Studies News Letter, No. 37 (June 2005).

14 State Council, Several Decisions concerning the Entry of Non-State Capital into Cultural Industries, Guofa [2005] No. 10 (13 April 2005), para.9. Despite the restriction, an increasing number of private companies have entered the publishing business unofficially and are operating in a grey area.

15 The Industry Catalogue, originally issued in 1995 and revised in 1997, 2002, 2004 and 2007, has consistently listed news organizations, newspapers, publishing houses, radio and TV stations, and importation of various cultural products under the category of "Prohibited" sectors for foreign investment.

16 Stanley Lubman, Looking for Law in China, 20 Columbia Journal of Asian Law (2006), 1, 21.

17 State Council, Regulation on the Administration of Publications, Order No. 343 (25 December 2001), art. 26, quoted in Panel Report, para.7.760.

18 Liebman, above n. 13 , at $41-42$.

19 Id., n. 168.

20 Id., at 42. 
State-owned entities whose management personnel are controlled by the government. It is for this reason that the government has kept State import monopoly in the cultural sector. By entrusting a small group of SOEs with the task of importing cultural products, the Party can exert control over foreign content most effectively and efficiently.

13. There is no question that the current system is anti-competitive-a small number of SOEs are guaranteed monopoly profits in the fast-growing content industry. And these SOEs have a vested interest in maintaining the status quo. However, China's policy of maintaining State import monopoly in cultural products is fundamentally driven by political rather than economic reasons. The political nature of this policy can also be observed from the absence of the usual trade barriers: China does not impose tariffs or quotas on the imports of reading materials or audiovisual products. Although the SOE importers may restrict the quantity of particular imports at government behest, under the current system they also have financial incentives to maximize imports for profit. ${ }^{21}$

14. In the light of the political nature of this policy and the consistency with which this policy has been implemented under Chinese law, it should be evident that the Chinese government never intended to liberalize trading rights in the cultural sector. It was simply not possible that the Chinese government would deem State trading in foreign publications as less important than in vegetable oil or chemical fertilizer. The Chinese negotiators apparently neglected to include cultural products in the State trading list of Annex 2A of the Accession Protocol. The government officials may well have taken for granted the exclusion of cultural products from the trading rights commitments. From their perspective, it would not be necessary to mention cultural products in Annex $2 \mathrm{~A}$, just as it would not necessary to mention weaponry and military equipment, the trading of which is also restricted to designated SOEs.

\section{I.B. The WTO decision on trading rights}

15. The dispute over trading rights was brought by the United States on 10 April $2007 .{ }^{22}$ The United States claimed that China was acting inconsistently with its

21 See above n.13. In addition to being financially independent, the SOE importers can keep all their profits. China only began to require certain SOEs to pay dividends to the government in 2008, which did not include the SOE content importers. For the new dividend policy, see Andrew Batson, China Seeks Funds from State Firms: Many State Enterprises Must Pay Higher Dividends as Their Role Is Reassessed, Wall Street Journal, 9 November 2010 (online.wsj.com).

22 The United States simultaneously filed another WTO case, complaining about the lack of protection of intellectual property rights in China. The United States won a limited victory in the case. See Panel Report, China-Measures Affecting the Prorection and Enforcement of Intellectual Property Rights, WT/DS362/R, adopted 20 March 2009 (China-IP Rights). Both cases were driven by the US content industry, which was interested in boosting exports to China while protecting its products from rampant copyright piracy in the country. 
obligations under the Accession Protocol "by not allowing all Chinese enterprises and all foreign enterprises and individuals to have the right to import into the customs territory of China the following products (collectively, the 'Products'): films for theatrical release, publications (e.g., books, magazines, newspapers and electronic publications), audiovisual home entertainment products (e.g., video cassetres and DVDs), and sound recordings." ${ }^{23}$ The United States identified ten Chinese regulations and rules as the measures at issue.

16. The Panel issued its report on 12 August 2009. It was relatively straightforward for the Panel to find that the various measures at issue were inconsistent with China's trading rights commitments, since cultural products are not among the products reserved for State trading under Annex $2 \mathrm{~A}$ of the Accession Protocol. ${ }^{24}$

17. In defending its measures, China invoked GATT Article XX(a), which allows a Member to adopt or enforce measures "necessary to protect public morals." China's defence raised two major interpretive questions: (1) whether GATT Article XX is applicable to the Accession Protocol; and (2) if so, whether China's measures meet the requirements of Article XX(a).

18. On the applicability of GATT Article XX, the Panel decided not to answer the question directly. Instead, it applied Article XX(a) on an arguendo basis. ${ }^{25}$ This approach allowed the Panel to examine whether China's measures satisfy the requirements of Article XX(a) on the assumption that the article applies. Only if the result of that examination were positive would it need to revert to the issue of applicability of Article XX.

19. On the requirement of Article XX(a), China claimed that its restrictions on the right to import cultural products are "necessary to protect public morals" because such restrictions ensure an effective and efficient content review mechanism. According to China, only the selected SOEs have a suitable organizational structure, an appropriate geographic coverage and a reliable, competent and capable personnel to perform the content review tasks properly. ${ }^{26}$ Countering China's arguments, the United States claimed that SOE import monopolies are not necessary for content review because content review is independent of importation and can be performed by individuals or entities unrelated to the importation process. ${ }^{27}$

23 Request for the Establishment of a Panel by the United States, WT/DS363/5 (11 October 2007).

24 Panel Report, para.7.706.

25 Panel Report, paras.7.744-7.745. The United States invited the Panel to follow this approach, which was adopted by the Appellate Body in United States-Measures relating to Shrimp from Thailand (DS343), United States-Customs Bond Directive for Merchandise Subject to Antidumping/Countervailing Duties (DS345), WT/DS343/AB/R, WT/ DS345/AB/R, adopted 1 August 2008, paras.304-319.

26 Panel Report, para.7.715.

27 Panel Report, paras.7.717-7.718. 
20. Although this is the first case involving interpretation of GATT Article XX(a), the Appellate Body has interpreted the "necessity" test under GATT Article XX(b) and (d), ${ }^{29}$ as well as GATS Article XIV(a) ${ }^{30}$ which contains a similar public morals exception as GATT Article XX(a). The previous cases have established that assessing "necessity" involves a process of "weighing and balancing" several factors, including (i) the relative importance of the interests furthered by the challenged measure, (ii) the contribution of the measure to the realization of the ends pursued, and (iii) the restrictive impact of the measure on trade. In addition, the panel must consider whether there is a reasonably available alternative that would make an equivalent contribution to the achievement of the ends pursued, but have a less trade-restrictive effect than the measure at issue.

21. Applying the necessity test in this case, the Panel first considered the interests to be furthered by the measures at issue. It noted that the United States did not specifically argue that China's measures were not measures to protect public morals, but rather challenged the means China chose to achieve the objective of protecting public morals. ${ }^{31}$ The Panel therefore had no difficulty in establishing the link between content review and public morals, finding that the protection of public morals is a highly important value and that China has adopted a high level of protection within its territory. ${ }^{32}$

22. The Panel, however, was "not persuaded" that the State-ownership requirement of import entities made a "material contribution" to the prorection of public morals. ${ }^{33}$ In response to China's arguments that only SOEs are suitable to conduct content review because they have proper organizations and qualified personnel and are able to bear the high costs associated with content review, the Panel stated that it was "not convinced" that the associated costs would be so high as to make it impossible, or not worthwhile, for private enterprises to attract

28 For example, AB Report, Brazil-Measures Affecting Imports of Retreaded Tyres, WT/ DS332/AB/R, adopted 17 December 2007 (Brazil-Tyres).

29 For example, $A B$ Report, Korea-Measures Affecting Imports of Fresh, Chilled and Frozen Beef, WT/DS161, 169/AB/R, adopted 10 January 2001.

30 AB Report, United States-Measures Affecting the Cross-border Supply of Gambling and Betring Services, WT/DS285/AB/R, adopted 20 April 2005 (US-Gambling).

31 Panel Report, paras.7.756, 7.762-7.763.

32 Panel Report, paras.7.816-7.819. The lack of scrutiny on what constitute "public morals" in this case was criticized by Pauwelyn, above n.9, at 14-17.

33 Panel Report, para.7.863. In this regard, the Panel found that one group of the measures, which set the "criteria" for selecting import entities (the "criteria provisions"), was apt to make a "material contribution" to the protection of public morals, but ultimately found that the criteria provisions failed the necessity test because there was a less restrictive alternative available. The AB reversed the Panel's finding on "material contribution" of the criteria provisions, but upheld the Panel's application of the less restrictive test to them. See AB Report, paras.299, 332. 
qualified personnel or obtain the organizational know-how needed to conduct content review properly. ${ }^{34}$

23. Regarding the restrictive impact, the Panel received no evidence that the measures restricted imports. ${ }^{35}$ But the Panel decided to examine, additionally, the impact of the measures on those who may wish to engage in importing cultural products. ${ }^{36}$ Since the measures prohibit all private domestic and foreign entities from engaging in importation of cultural products, their restrictive impact on potential importers is complete. Weighing the high value of protecting public morals against the severe restrictive impact on potential importers and the lack of a material contribution of the measures to the goal, the Panel was able to conclude that the measures were not "necessary" to protect public morals. ${ }^{37}$

24. The Panel further examined the "reasonably available alternative" with respect to some of the measures challenged. It found that the US proposal that the Chinese government be given the sole responsibility for the conduct of the content review is such an alternative, because it would make an equivalent or better contribution to the objective of protecting public morals, but with a significantly less restrictive impact on potential traders. ${ }^{38}$ Although the Panel recognized that the proposed alternative might require China to allocate additional human and financial resources to the task of content review, it found the alternative to be reasonably available because China had not demonstrated that it would impose "an undue burden", financially or otherwise. ${ }^{39}$ Having made this finding, the Panel was able to reach its overall conclusion that China's measures are inconsistent with its trading rights commitments and, assuming Article XX(a) applies, such inconsistency cannot be justified by Article XX(a). ${ }^{40}$

25. On appeal from China, the Appellate Body upheld all the key findings of the Panel. Significantly though, the AB disagreed with the Panel's approach of applying Article XX to the Protocol provisions on an arguendo basis. Instead, it held that China may invoke GATT Article XX(a) directly as a defence for the breach of its trading rights commitments under the Accession Protocol. The AB decision will be analysed in Section III.

34 Panel Report, para.7.858.

35 Data submitted by China showed that imports of reading materials and audiovisual products increased significantly between 2002 and 2006. Id., para.7.807.

36 Panel Report, para.7.788.

37 Id., paras.7.837-7.868.

38 Id., para.7.899.

39 Id., paras.7.903-7.906.

40 Since China's measures did not meet the necessity test, the Panel did not examine the requirement of the chapeau of Article XX that such measures "are not applied in a manner which would constiture a means of arbitrary or unjustifiable discrimination between countries where the same conditions prevail, or a disguised restricrion on international trade". Id., para.7.912. 


\section{I.C. Status of compliance}

26. China declared its intention to implement the WTO rulings, but requested a reasonable period of time to do so. In July 2010, China and the United States reached an agreement that the reasonable period for China to comply should be 14 months from the date of adoption of the $A B$ and Panel Reports, that is, until 19 March $2011 .^{41}$

27. On 14 March 2011, China notified the DSB that it had "completed amendments to most measures at issue". Considering the dispute is embodied with "more complexity and sensitivity than other disputes", China hoped that "relevant WTO Members could understand the difficult and complicated situation China is facing during the process of implementation". 42

28. On 19 March 2011, the State Council of China issued amendments to the Regulations on the Management of Publications ${ }^{43}$ and the Regulations on the Management of Audiovisual Products. ${ }^{44}$ Pursuant to the amended Regulations, only entities specifically approved by the government may engage in the importation of reading materials and audiovisual products. ${ }^{45}$ This contrasts sharply with China's registration-only system for the importers of other products. ${ }^{46}$ On the qualifications of importers, the amended Regulations eliminated the requirement that importers be wholly State-owned and specifically designated by the government, but added a requirement that the importer must have the ability to conduct content review. ${ }^{47}$ It remains to be seen whether in practice the government will approve private and foreign entities to be importers, and if so, under what conditions.

29. At the time of writing, revisions of other regulations are still under consideration, including the regulation on the right to import foreign films. On 2 April 2011, the government published a draft Catalogue for Guidance of Foreign Investment Industries for public comments. ${ }^{48}$ The draft Catalogue deleted from the "Prohibited" category foreign investment in the importation of publications and audiovisual products. Presumably, such investment will become permitted. However, because under Chinese law all foreign investment projects must be specifically approved by the government, this revision to the Catalogue will not result in the right to import cultural products being automatically granted to foreign investors.

41 WT/DS363/16 (13 July 2010).

42 WT/DS363/17/Add.2 (15 March 2011).

43 State Council Order No. 594 (19 March 2011) (Regulations on Publications).

44 State Council Order No. 595 (19 March 2011) (Regulations on Audiovisuals).

45 See Regulations on Publications, arts. 41, 43; Regulations on Audiovisuals, art. 27.

46 See above text to n.11.

47 See Regulations on Publications, art. 42.

48 Notice of Solicitation of Public Comment on the Amended Catalogue for Guidance of Foreign Investment Industries (www.gov.cn/gzdt/2011-04/02/content_1836908.htm). 
30. In sum, judging from the regulatory changes made or proposed thus far, China has not complied with the WTO ruling requiring it to grant the right to import cultural products in accordance with its trading rights commitments, that is, to grant such right to "all enterprises in China" and "all foreign individuals and enterprises" in a "non-discriminatory and non-discretionary" manner. ${ }^{49}$ Although the formal requirement of State ownership of importers has been removed, the government has retained full discretion in approving importers, and the actual criteria for approval remain unclear.

\section{Implications of the WTO decision for China's domestic system}

31. To understand why China has not been able to fully implement the WTO ruling on trading rights, it is necessary to examine the ruling's implications for China's domestic system. Because China's restrictions on trading rights are political and systemic in nature, the removal of these restrictions would have political and systemic consequences for China.

\section{II.A. Implications for economic reform}

32. While State ownership continues to dominate China's media and culture sectors, the government has been pushing commercialization of the sectors in the past decades. The major policy measures taken include the transformation of SOEs into for-profit enterprises, and a gradual easing of the restrictions on the entrance of private enterprises into the sectors. ${ }^{50}$ As a result, a marketplace with fierce competition has emerged, and the media and cultural industries have flourished. ${ }^{51}$

33. In the wake of the global financial crisis, the government has adopted a new policy of encouraging a broader participation of private capital in the traditionally State-dominated sectors. A key policy document issued by the State Council in May 2010 identifies several areas in the cultural industry, including printing, distribution of publications and the Internet culture, as among the industries in which private

49 Above n. 10.

50 According to the China Internet Information Center, an authorized government portal site, while public ownership is the mainstay, non-public ownership participates in 90 per cent of the 357000 press and publishing companies in China, including over 2500 printing businesses and more than 40 distribution companies that are joint ventures with foreign investment. See Background Materials on the Reform and Development of the Press and Publication Sectors (20 August 2010) (www.china.org.cn/china/2010-08/20/ content_20756721.htm).

51 In 2009, China saw the publishing of 302000 titles, 1937 newspapers, 9851 periodicals, 25384 audiovisual products and 10708 e-publications. China ranked first, first, second and third in the world in terms of the size of daily newspaper publishing, the total number and print run of titles, the size of e-book publishing and total output of the printing and reproduction business, respectively. Id. 
investment is to be encouraged. ${ }^{52}$ The general trend, therefore, is towards further relaxation of ownership control and promoting greater diversity in the cultural sector.

34. Despite this general trend, importation of cultural products has remained offlimits to non-State-owned entities. The implementation of the WTO ruling, therefore, would not only benefit foreign companies wanting to sell their content products directly to Chinese consumers, but more significantly, it would help advance privatization in the cultural sector. Whether the government is prepared to dismantle this bastion of State ownership, however, will depend on whether its censorship regime can be reformed.

\section{II.B. Implications for the censorship regime}

35. Although the WTO decision does not require China to reduce its political censorship or change its censorship criteria, it does require China to alter the way in which its censorship on imports is conducted. The required changes would affect not only the institutional setup but also the operation and effect of the censorship regime.

\section{II.B.i. Restructuring of government apparatus}

36. Under the existing system, content review of imports is conducted by different institutions. For books, newspapers and periodicals, day-to-day content review is performed by the import entities designated by the General Administration of Press and Publication (GAPP). As of 2008, 42 wholly State-owned entities were approved to import reading materials into China. ${ }^{53}$ The importing entities submit to the GAPP, prior to importation, a list of materials intended for importation. While the GAPP may intervene in day-to-day content review after receiving the list, it mainly exercises a supervisory role by conducting annual inspections of the import entities. ${ }^{54}$ For electronic publications, the GAPP performs final content review of samples brought into China through temporary import procedures. ${ }^{55}$ For audiovisual products, only one wholly State-owned entity has been approved to import finished products. ${ }^{56}$ Similar to electronic publications, the GAPP conducts final content review of samples of audiovisual products temporarily imported. ${ }^{57}$ As for films for theatrical release, China has an import quota of 20 motion pictures per year. ${ }^{58}$ Only one wholly State-owned entity is approved to

52 See Several Opinions of the State Council on Encouraging and Guiding Healthy Development of Private Investment, Guofa [2010] No. 13 (7 May 2010) (also known as "the New 36 Provisions"), art. 17.

53 AB Report, fn. 251.

54 AB Report, para. 145.

55 Id.

$56 \mathrm{AB}$ Report, para.153. It is unclear how many entities are approved to import unfinished audiovisual products. Id., fn.281. 
import them, and the government agency responsible for reviewing imported samples is the State Administration on Radio, Film and Television. ${ }^{59}$

37. If China were to accept the censorship method proposed by the WTO, it would need to centralize content review of all printed imports, which would require the GAPP to set up a new government agency to handle the tremendous volume of such imports. The existing central review agencies for electronic publications and audiovisual products would also need to expand their capacities signifcantly in order to handle the submission of samples by numerous domestic and foreign importers. To these ends, the government would need to hire and train a large number of additional personnel to perform content review so as to cover all geographic regions in China, and might need to relocate many in-house content reviewers currently employed by the dozens of SOE importers. In addition to the substantial cost involved, the bureaucratic reorganization could have a disruptive effect on the lives of numerous government employees. As China submitted, the government restructuring required would be "tremendous". 60

\section{II.B.ii. Transparency and due process}

38. The most significant impact of the WTO ruling, however, would be on the procedural aspects of China's censorship regime. Currently, the designated SOE importers determine, through their internal review process, whether the content of a particular item falls within the prohibited categories. The specific criteria used by the SOEs are unknown to the public and the entire review process is nontransparent.

39. The secrecy of China's censorship criteria is by design. Through internal Party channels, the Central Propaganda Department (CPD), the most powerful body in the censorship regime, issues directives and guidelines and coordinates with the government agencies in charge of the media and cultural industries to implement its instructions. ${ }^{61}$ The CPD adjusts its censorship criteria constantly as it reacts to current events and developments, trying to balance the need for information, which is critical for the nation's economic development, with the need to prevent the type of freedom of information that may lead to the downfall of the Communist Party. ${ }^{62}$ The CPD instructions are deemed "State secrets", the

57 Prior to March 2011, the authority to conduct such review was vested in the Ministry of Culture. See Regulations on Audiovisuals, above n.44, art. 28.

58 Accession Protocol, China's Services Schedule, Section 2D.

59 AB Report, para.159 and fn.294.

60 AB Report, para.322.

61 See Council on Foreign Relations, Media Censorship in China, by Preeti Bhattacharji, Carin Zissis and Corinne Baldwin (27 May 2010) (www.cfr.org/publication/11515/ media_censorship_in_china.html).

62 The media policy of the Party has been in the state of "schizophrenia", as it goes back and forth, constantly testing the line. Id. 
publicizing of which may lead to severe punishment. ${ }^{63}$ In addirion to the desire for flexibility, the Party also has no interest in publicizing the titles of banned materials lest it would stoke heightened interest in the "forbidden fruit", increasing the risk of smuggling and underground circulation of the banned materials. ${ }^{64}$ This system is by now deeply entrenched.

40. Interestingly though, Chinese citizens have begun to challenge the opacity of the censorship regime. It was widely reported that a Chinese scholar sued a customs office in Guangzhou over the confiscation of books he brought back from Hong Kong. ${ }^{65} \mathrm{He}$ claimed that the seizure was unlawful because the customs refused to show him the internal document that supposedly listed those books as banned and that there was no index of banned books publicly available. According to the reports, similar cases had been lodged against the customs in Beijing and Fuzhou previously. ${ }^{66}$ Unsurprisingly, however, none of the plaintiffs prevailed in those lawsuits.

41. The particular design of China's censorship regime works effectively and efficiently with SOEs because their personnel are trusted and effectively controlled by the government. In contrast with this SOE-based censorship regime, if all content review of imports were to be performed by a central government agency, as recommended by the WTO, that agency might soon be under public pressure to make the censorship process more transparent. Imagine if numerous foreign companies were to be prevented from importing various contents and the government would not explain why the particular content was disallowed. Sooner or later, some importers would begin to complain about the lack of due process and transparency in the process, and such complaints would be widely reported.

42. Furthermore, unlike the Chinese cases mentioned above, a lack of transparency and due process in the review process for commercial imports would raise an issue of WTO inconsistency. GATT Article X, for example, requires a Member to publish all of its laws, regulations, judicial decisions and administrative rulings of general application pertaining to trade in goods. ${ }^{67}$ Violations of Article $\mathrm{X}$ have

63 A journalist was detained in 2004 and sentenced to ten-year imprisonment for posting an online summary of the CPD instructions on how to report the 15-year anniversary of events at the Tiananmen Square. Id.

64 In addition, when people do not have a clear sense of what are being censored, they may be oblivious to the effect of censorship, hence more likely to tolerate the regime. See Loretta Chao and Jason Dean, China's Internet Censors Thrive by Confusing Web Users, Wall Street Journal, 1 April 2010 (online.wsj.com).

65 See People's Daily Online, Customs Rejects Scholar's Appeal for Held Books, (english. peopledaily.com.cn/90001/90782/90872/6850684.html), 24 December 2009; YANG Zheng, Customs Seizes "Banned Books"; What Is the Basis?, Nanfang Zhoumo [Southern Weekend], 22 October 2009.

66 Southern Weekend, id.

67 GATT Article X:1. Similar provisions are contained in GATS Article III. GATT Article X:1 further provides that a member is not required to disclose "confidential information which 
given rise to an increasing number of WTO claims. ${ }^{68}$ In addition to the generally applicable WTO rules, China is also subject to more stringent requirements of transparency and due process under the Accession Protocol. ${ }^{69}$ One of the Chinaspecific transparency requirements has already been involved in a WTO dispute. ${ }^{70}$ It is not inconceivable, therefore, that China's opaque and arbitrary content review process could one day become the target of WTO complaints.

\section{II.B.iii. Censorship effect}

43. The WTO decision is not meant to affect the level of China's censorship. However, if China were to adopt the WTO proposal and centralize all pre-importation review, the censorship on imports might become more restrictive than that under the SOE in-house review system. That is because a centralized pre-importation review system would create a very different set of incentives. Currently, the trusted SOE importers enjoy a great deal of discretion in interpreting the vaguely worded censorship criteria. Their in-house reviewers do not necessarily share the same political sensibility with the Party conservatives, and many veterans in the business may favour a more liberal policy. ${ }^{71}$ Financially, since the SOEs are responsible for their own operations, it is also not in their economic interest to construe the criteria too strictly in order to restrict imports. ${ }^{72}$

44. In contrast, if all content review were to be tasked to a government agency independent of import entities, the incentives of its employees would be quite

would impede law enforcement or otherwise be contrary to the public interest". It is unclear whether the confidentiality of censorship criteria could be construed as falling within this exception.

68 See Padideh Ala'i, From the Periphery to the Center? The Evolving WTO Jurisprudence on Transparency and Good Governance, 11 JIEL (2008), 1.

69 See Accession Protocol, paras.2(C) and 2(D). For analysis, see Qin, above n.6, at 491-497. Note that the China-specific transparency requirements are not subject to any exception under the Accession Protocol, in contrast with GATT Article X:1. See above n.67.

70 See China-Measures concerning Wind Power Equipment, Request for Consultation by the United States, WT/DS419/1 (6 January 2011). The United States claimed, inter alia, that China has not made available a translation of these measures into one or more of the official languages of the WTO, in violation of its obligation under the Accession Protocol.

71 In this regard, see an open letter condemning political censorship, authored by 23 Party elders, including former chief editors and top officials of more than a dozen major Chinese newspapers, journals, publishing houses and TV station, at China Media Project, Open Letter from Party Elders Calls for Free Speech (cmp.hku.hk/2010/10/13/8035/). See also Jeremy Page, Chinese Elders Blast Censorship, Wall Street Journal, 14 October 2010 (online.wsj.com). The core demand of the open letter was to abolish all pre-publication censorship by the government in favour of a true editor responsibility system. Ironically, the WTO judiciary has directed China to move in an opposite direction: centralizing pre-publication reviews by the government on all cultural imports.

72 The discretion combined with the financial incentives has resulted in media that increasingly seek to appeal to the public, and are willing to push the limits of permissible content. See Liebman, above n.13, at 58-59. 
different. Accountable to the central censorship agency only, the reviewers would be motivated to screen imports as rigorously and strictly as possible so as to justify their bureaucratic existence. Such a phenomenon has already been observed in the Internet censorship, where the number of blocked contents tends to grow over time, thanks in no small part to the alleged 30000 -strong army of professionals hired to police the Net. ${ }^{73}$

45. If, in combination with a centralized review system, the government should impose a legal duty on all private importers to self-censor, the restrictive effect of the censorship would be even greater. As the experience in the Internet censorship shows, when private businesses are required by law to practise self-censorship, they tend to err on the side of caution and over-censor content that does not clearly violate the rules. ${ }^{74}$ In other words, private importers might be inclined to go in the direction opposite from that of the SOE importers who, with the trust of the government, tend to push the envelope by importing content that might otherwise be questionable.

\section{II.C. Implications for foreign trade}

46. Liberalizing trading rights in cultural products will require changes in customs procedures that may adversely affect trade flow. ${ }^{75}$ Currently, with trusted SOEs in charge of content imports, customs authorities can clear their goods with minimum inspection. Should numerous private and foreign entities become importers of content products, customs would need to tighten inspections significantly. The government would be especially concerned with smuggling of anti-government content, such as those disseminated by a group banned by China as an "evil cult", 76 through private importers. As a result, the process of customs clearance could be lengthened.

73 Established in 2000, the Internet police force reportedly employs 30000 monitors and operates as a division within the police departments of 700 cities and provinces in China. CRS Report for Congress, Internet Development and Information Control in the People's Republic of China, 22 November 2005 (www.cfr.org/publication/).

74 See Human Rights Watch, "Race to the Bottom": Corporate Complicity in Chinese Internet Censorship, August 2006, Vol. 18, No. 8(C), 14 (www.hrw.org/reports/2006/china0806/ index.htm). See also Clive Thompson, Google's China Problem (and China's Google Problem), New York Times, 23 April 2006 (reporting that as a result of the vague censorship criteria and self-censor obligations, Internet executives in China most likely censor far more material than they need to).

75 During the Panel proceeding, China argued that requiring the government to be solely responsible for conducting the content review may adversely affect the efficiency of the content review and trade flows because of the large quantities of reading materials imported, the time constraints for newspapers and periodicals and the numerous customs entry points through which reading materials are being imported. See Panel Report, paras.7.889-7.891.

76 This group in exile has been aggressive in producing publications overseas condemning the Communist Party, including a newspaper distributed for free in eight languages and 30 countries. See Thomas Lum, CRS Report for Congress, RL 33437, 11 August 2006. 
47. It is difficult to predict whether liberalization of trading rights would result in a significant increase in China's cultural imports. On the one hand, when Chinese consumers can buy from foreign producers directly, rather than going through State-designated importers, they should be able to get a betrer price, thus increasing the consumption of foreign content. And imports of certain types of products, such as religious titles, could grow significantly if no import ban or quotas are imposed. On the other hand, the government might decide to charge fees for performing content review externally, as suggested by the WTO decision, ${ }^{77}$ which could offset or reduce the pricing gains from direct purchases.

48. It is also possible that the volume of imports will be negatively affected if content review is moved from SOE in-house to an external agency, due to a different alignment of incentives. As previously explained, the designated SOEs have financial incentives to import as much as possible in order to earn a profit. Data submitted to the WTO indicate that the volume of cultural imports grew considerably under the current system. ${ }^{78}$ In contrast, if the content review were to be tasked to a central government agency, the natural tendency would be for the review process to be tightened. Furthermore, if potential private importers were required to self-censor, there might be a chilling effect further discouraging imports.

\section{II.D. Future prospects for compliance}

49. Prior to this case, China had kept a perfect record of complying with adverse WTO decisions. In the first two cases in which its measures were found to be WTO-inconsistent, ${ }^{79}$ China fully implemented DSB rulings, including making amendment to major national legislation. ${ }^{80}$ And it had every incentive to keep that record. Being the top exporter in the world, China relies on the WTO system to maintain an open global trading environment. Non-compliance with DSB rulings would cost dearly in political capital as China fights against protectionist trends in the post-financial crisis era.

50. Domestically, however, the political climate has not been conducive to making the type of systemic changes required by the WTO ruling. Threatened by rising social unrest in recent years, the government has been tightening its grip

77 In response to China's argument that the proposed alternative would be too expensive, the Panel suggested that China could in any event charge fees for providing content review services so as to lessen the financial burden of the government. Panel Report, para.7.905.

78 From 2002 to 2006, the number of newspaper titles imported into China increased from 586 to 767 , the number of titles for periodicals increased from 36032 to 45178 and that for audiovisual products from 11464 to 31 123. Panel Report, para.7.807.

79 See AB Report, China-Measures Affecting Imports of Automobile Parts, WT/DS339, 340, 342/AB/R, adopted 12 January 2009; and China-IP Rights, above n.22.

80 China amended the Copyright Law to comply with the DSB rulings in China-IP Rights. See WT/DS362/14/Add.2 (9 March 2010). 
on the media, the Internet and the censorship machine. ${ }^{81}$ If there was previously some hope that the Party reformists might be able to embrace the WTO decision and leverage it to advance their political reform agenda, ${ }^{82}$ any such hope has been dashed after anonymous online calls for a revolution in China prompted the government to react with harsh crackdowns. ${ }^{83}$

51. In response to China's failure to meet the deadline for implementation, the United States may initiate additional WTO proceedings to compel compliance. ${ }^{84}$ Under the current political climate, however, the prospects for full compliance remain poor.

52. A lack of full compliance can lead to an eventual request by the United States for WTO-sanctioned trade retaliations. In this regard, China may take to heart the United States' practice in US-Gambling, ${ }^{85}$ a case that bears a certain resemblance to China-Publications. In that case, Antigua challenged the US regulations prohibiting Internet gambling as a breach of the US commitment to liberalize "recreational services" under the GATS. The United States contended that its services commitments did not include Internet gambling. To justify its measures, the United States also invoked the public morals exception of GATS Article XIV(a), which contains similar language as GATT XX(a). Siding with Antigua, the WTO judiciary found that the United States had committed to liberalize Internet gambling, and that while its measures were designed to protect public morals, the United States had failed to demonstrate that the measures met the non-discrimination requirements under the chapeau of Article XIV. ${ }^{86}$ After losing the case, the

81 See above n.61. See also Guardian, Timeline: Chinese Internet Censorship over the Last Year, 14 January 2010 (www.guardian.co.uk); Xinhua News Agency, China to End Anonymous Online Comments, 4 May 2010 (news.xinhuanet.com) (reporting government's push to end anonymous online comments and to prevent "overseas hostile forces from infiltrating through the Internet").

82 Premier Wen Jiabao made surprising calls for political reform in 2010. See, e.g., Reuters, China Premier Wen Calls for Political Reform, 22 August 2010 (www.reuters.com); Guardian, Wen Jiabao Talks Democracy and Freedom in CNN Interview, 4 October 2010 (www.guardian.co.uk). It is well known that reformists within the Party successfully leveraged the WTO demands during the accession to advance their economic reform agenda in the late 1990s when facing domestic opposition to the reforms. Dongli Huang, Commentary on "Trade, Investment and Beyond", 191 The China Quarterly (September 2007), 742, 743.

83 See A. Ramzy, State Stamps Out Small 'Jasmine' Calls in China, Times, 21 February 2011 (www.time.com/time/); D. Pierson, Online Call for Protest in China Prompts Crackdown, Los Angeles Times, 26 February 2011 (articles.larimes.com); Reurers, Beijing Says "Jasmine Protest" Calls Doom to Fail, 6 March 2011 (www.reuters.com).

84 BNA WTO Reporter, U.S. Faults China's Implementation of Ruling on Audiovisual, Hints of Further WTO Action, by Daniel Pruzin, 28 March 2011.

85 AB Report, above n.30.

86 Id., para.369. This AB decision has received much criticism. See, e.g., Joost Pauwelyn, Rien ne Va Plus? Distinguishing Domestic Regulation from Market Access in GATT and GATS, 4 
United States claimed it had committed an "oversight" in drafting its services schedule. ${ }^{87}$ Instead of removing the restrictions, the United States has since renegotiated its schedule with other Members to exclude gambling from its GATS commitments. ${ }^{88}$ With respect to Antigua, the United States has accepted WTO-sanctioned trade retaliation of $\$ 21$ million per year. ${ }^{89}$ Similar to the United States in US-Gambling, China could also claim an oversight in drafting the coverage of its trading rights commitments. Unlike the United States, however, China might not be able to renegotiate its commitments due to the legal uncertainty surrounding possible amendment to the Accession Protocol..$^{90}$ Nonetheless, China may follow the US example in accepting WTO-sanctioned retaliation, ${ }^{91}$ especially if the amount is manageable. ${ }^{22}$

53. The dispute may be resolved eventually through a negotiated settlement. Instead of complete liberalization, China may agree to allow selected foreign entities to import certain types of content products. ${ }^{93}$ In exchange for accepting such partial liberalization, the United States may demand additional market access in other sectors as compensation. It might take years before a deal can be reached, and

World Trade Review (2005), 131; Federico Ortino, Treaty Interpretation and the WTO Appellate Body Report in US-Gambling: A Critique, 9 JIEL (2006), 117; Petros C. Mavroidis, Highway XIV Revisited: The Road of Non-discrimination to Market Access in GATS, 6 World Trade Review (2007), 1; Douglas A. Irwin and Joseph Weiler, Measures Affecting the Cross-border Supply of Gambling and Betting Services (DS 285), 7 World Trade Review (2008), 71, 89-95.

87 See Statement of Deputy United States Trade Representative John K. Veroneau regarding U.S. Actions under GATS Article XXI, 4 May 2007 (www.ustr.gov).

88 In December 2007, the USTR confirmed that it had reached agreement with Canada, the EU and Japan under the GATS Article XXI process. The United States agreed to liberalize markets for warehousing services, technical testing, research and development services and postal services relating to outbound international letters. USTR: Statement on Internet Gambling, 21 December 2007 (www.ustr.gov).

89 The authorized retaliation is in the form of suspension of Antigua's obligations to protect US intellectual property rights under the Agreement on Trade-relared Aspects of Intellectual Property Rights (TRIPS). See WTO Arbitration Award in US-Gambling, WT/DS285/ ARB, 21 December 2007.

90 The Accession Protocol is silent as to whether its terms may be amended. For detailed analysis, see Qin, above n.7, at 133-135.

91 See $\mathrm{Wu}$, above $\mathrm{n} .9$, fn. 55 (indicating that a proposal was made for China to follow suit with US's non-compliance in US-Gambling).

92 The Unired States submitted no evidence on the adverse effect of the trading rights restrictions on trade. See above text to n.35. It remains to be seen how the amount of trade retaliation will be calculated on the basis of the adverse effect of the measures on potential importers.

93 Some content products, such as music, science and technology materials, are not so politically sensitive. Given the small import quota on films, liberalizing the right to import films should not make content review unmanageable. 
any deal between the two countries must be extended to all other WTO members on a non-discriminatory basis.

\section{New jurisprudence on trading rights}

54. China-Publications has generated new jurisprudence on the interpretation of China-specific rules within the WTO multilateral legal framework. This Section will evaluate the new jurisprudence concerning (1) the applicability of GATT Article XX to the Accession Protocol and (2) the trader-based necessity test under GATT Article XX(a).

\section{III.A. Applicability of GATT Article XX to the Accession Protocol}

55. Technically, the Accession Protocol is a bilateral agreement concluded between China and the WTO, distinct from the multilateral agreements concluded among members of the WTO. At the same time, however, the Protocol is also made an "integral part" of the Agreement Establishing the World Trade Organization (the WTO Agreement), the umbrella agreement to which all other multilateral WTO agreements are annexed. ${ }^{94}$ This dual status of the Accession Protocol raises major issues for interpretation in that it is not clear how the numerous China-specific obligations prescribed by the Accession Protocol should be "integrated" with the generally applicable obligations under the multilateral WTO agreements. ${ }^{95}$ One such integration issue arose in this casewhether the general exceptions of GATT Article XX are available to the trading rights obligations under the Protocol-an issue of "broad systemic import" for the WTO. ${ }^{96}$

56. As previously noted, the Appellate Body rejected the Panel's approach to apply Article XX on an arguendo basis and instead tackled the systemic issue directly. According to the $\mathrm{AB}$, while the arguendo technique may enhance simplicity and efficiency in decision-making, it may also detract from a clear enunciation of the relevant WTO law and create difficulties for implementation. In the AB's view, the use of the technique in this case "risks crearing uncertainty with respect to China's implementation obligations". ${ }^{97}$

57. In addressing the question of applicability of Article XX to the Accession Protocol, the Appellate Body focused on the first two sentences of paragraph 5.1 of the Accession Protocol, which sets out China's main commitment on trading rights ${ }^{98}$ :

94 For discussion on the legal nature of the Protocol and its relationship with other WTO agreements, see Qin, above n.7, at 132-138.

95 See id., 137.

96 Panel Report, para.7.739 (citing the view of the United States).

97 AB Report, paras.213-215.

98 The full scope of China's trading rights commitments is broader, see above n. 10 . 
Without prejudice to China's right to regulate trade in a manner consistent with the WTO Agreement, China shall progressively liberalize the availability and scope of the right to trade, so that, within three years after accession, all enterprises in China shall have the right to trade in all goods throughout the customs territory of China, except for those goods listed in Annex 2A which continue to be subject to state trading in accordance with this Protocol. Such right to trade shall be the right to import and export goods. (Emphasis added.)

58. China argued that the introductory clause of this paragraph (in italics above) enables it to invoke GATT Article XX(a) to defend its measures at issue. The AB, therefore, centred its interpretation on the meaning of the introductory clause. After a lengthy discussion on the text and context of the introductory clause, the $A B$ concluded that whether China may justify its measure under Article XX "must in each case depend on the relationship between the measure found to be inconsistent with China's trading rights commitments, on the one hand, and China's regulation of trade in goods, on the other hand." 99 It then found "a clearly discernible, objective link" between China's measures at issue and China's regulation of trade in the relevant products. Based on this finding, the $A B$ held that China may rely on the introductory clause of paragraph 5.1 to invoke GATT Article XX(a) to defend its measures found in violation of its trading rights commitments under the Accession Protocol. ${ }^{100}$

\section{III.A.i. A welcome development in WTO jurisprudence}

59. The AB's ruling is a significant development in WTO law in that it sanctions for the first time the use of a general exception under one WTO agreement as a defence for a claim made under another WTO agreement. For historical reasons, the WTO treaty structure is exceedingly complex and the relationship between provisions of different WTO agreements is not always clear. WTO rules on trade in goods, for example, consist of GATT 1994, which includes the text of GATT 1947 and various understandings on GATT provisions, and a dozen other WTO agreements, such as the Agreement on Subsidies and Countervailing Measures (SCM), the Antidumping Agreement, and the Safeguard Agreement, that elaborate and expand the original GATT disciplines. The relationship between the GATT and the other instruments on trade in goods, however, is not well articulated by treaty language. ${ }^{101}$ Among other things, it is unclear whether the general exceptions of the GATT can

$99 \mathrm{AB}$ Report, para.229.

100 AB, Report, paras.216-233.

101 The general interpretive note to Annex $1 \mathrm{~A}$ of the WTO Agreement provides a general principle that, in the event of conflict between a provision of GATT 1994 and a provision of another WTO agreement on trade in goods, the latter shall prevail. 
be invoked to defend claims made under other agreements that do not contain such exceptions.

60. When the question arose previously as to whether GATT Article XX can be invoked to justify a measure found to be inconsistent with the Antidumping Agreement, the Appellate Body resorted to the arguendo technique and avoided answering the question directly. ${ }^{102}$ The AB's reluctance to address the systemic issue was consistent with a strict textualist approach it adopted towards treaty interpretation. Under this approach, the $A B$ would follow the interpretive rules set out in Articles 31 and 32 of the Vienna Convention on the Law of Treaties (VCLT) ${ }^{103}$ in a rigid and mechanical manner. Rather than placing a treaty term in its systemic context, the $\mathrm{AB}$ would prefer to derive the meaning of the term from its dictionary definitions and narrow textual confines. The Appellate Body once declared that it would not condone "the imputation into a treaty of words that are not there". ${ }^{104}$ Accordingly, it was unwilling to find the applicability of GATT exceptions to another WTO agreement without any textual indication in the treaty. In more recent years, the $\mathrm{AB}$ has attempted to soften its strict approach, announcing that treaty interpretation "is ultimately a holistic exercise". ${ }^{105}$

61. Against this background, the AB's ruling on the availability of GATT Article $\mathrm{XX}$ to the Accession Protocol is a welcome development in WTO jurisprudence. Although the holding is closely pinned to the text of the introductory clause of paragraph 5.1, which refers to the WTO Agreement, its legal reasoning is potentially capable of a broader application. Specifically, the criterion announced by the AB for the availability of the GATT exceptions is the existence of a "clearly discernible, objective link" between the measures at issue and the regulation of trade in goods. ${ }^{106}$ Using this criterion, it should nor be difficult to establish the availability of GATT general exceptions to other WTO agreements regulating trade in goods, such as the Antidumping Agreement and the SCM. Perhaps more significantly, the AB made a general statement that the "right to regulate" is "an inherent power enjoyed by a Member's government, rather than a right bestowed by international treaties such as the WTO Agreement". ${ }^{107}$ This recognition of a Member's inherent power to regulate lends support to the argument that public policy exceptions such as those set out in Article XX are "inherently" available to the Member to justify a

102 See above n.25.

103 Done at Vienna on 23 May 1969; entered into force on 27 January 1980. 1155 UNTS 331.

$104 \mathrm{AB}$ Report, India-Patent Protection for Pharmaceutical and Agricultural Chemical Products, AB/DS50/AB/R, adopted 16 January 1998, para. 45.

105 AB Report, EC-Customs Classification for Frozen Boneless Chicken Curs, WT/269, 286/ AB/R, adopted 27 Seprember 2005 (EC-Chicken Cuts), para.176.

106 AB Report, paras.229-233.

$107 \mathrm{AB}$ Report, para.222. It went on to say that such regulatory power in trade is constrained by WTO disciplines prescribed by the WTO agreements. Id. 
derogation of a WTO obligation, and that the availability of such policy exceptions can only be contracted away by explicit treaty provisions, and not by mere silence of the treaty. ${ }^{108}$

62. Hence, even though the AB's ruling is based on a textual link found in paragraph 5.1 of the Accession Protocol, its reasoning may have opened the door for applying GATT/GATS general exceptions to other WTO agreements that are silent about such policy exceptions. ${ }^{109}$ Similarly, this reasoning could be used to find the availability of GATT/GATS exceptions to other China-specific provisions under the Accession Protocol that do not contain a similar qualifying clause as that of paragraph 5.1. ${ }^{110}$ In short, the AB's analysis has paved the way for interpreting the various agreements within the WTO as an integrated whole based on coherent policy considerations.

63. Some may see the $\mathrm{AB}$ ruling as an indication of "judicial activism", insisting that it is the WTO members, not its adjudicatory body, that should determine the relationship between the various WTO agreements. Ideally, large gaps between treaties should be filled by formal amendment or authoritative interpretations by the WTO Members. However, in the light of the practical difficulties in securing formal amendment or obtaining an authoritative interpretation from the Members, "11 it would be unrealistic to expect the "legislative" branch of the WTO to clarify the relationship between the various WTO agreements in the foreseeable future. For the sake of a better functioning of the WTO system, therefore, the $\mathrm{AB}$ ruling is to be welcomed.

64. Others may harbour doubts as to the soundness of the $A B$ ruling. They point to the text of GATT Article XX, which states that "nothing in this Agreement" shall prevent measures taken for the policy purposes set out therein. Since the Accession Protocol is not part of the GATT, the argument goes, Article XX cannot be applied

108 For a similar understanding, see Pauwelyn, above n.9, at 18 .

109 Pauwelyn also cautioned against opening the door too widely. Id., 19-20.

110 In an ongoing dispute, China has already asserted its inherent right to regulate under GATT Article XX to justify the breach of its commitment to eliminate all export tariffs under the Accession Protocol, despite that the provision setting out the commitment does not refer to the WTO Agreement. See China-Measures related to the Exportation of Various Raw Materials (DS394, DS395, DS398), U.S. Answers to the First Set of Panel Questions (13 September 2010), Q. 35 (www.ustr.org).

111 To date, there has been only one amendment made to the WTO Agreement (Amendment to the TRIPS Agreement, WT/L/641 (8 December 2005)). The amendment has not yet taken effect as it has not been accepted by two-thirds of the Members as required by Article X:3 of the WTO Agreement. Pursuant to Arricle IX:2 of the WTO Agreement, the Ministerial Conference and the General Council have the exclusive authority to adopt interpretations of the WTO Agreement. However, no such authoritative interpretation has ever been made. See Claus-Dieter Ehlermann and Lothar Ehring, The Authoritative Interpretation under Article IX:2 of the Agreement Establishing the World Trade Organization: Current Law, Practice and Possible Improvements, 8 JIEL (2005), 803. 
to the Accession Protocol. This view seems widespread, including one expressed by the EU as a third party in this case ${ }^{112}$ and acknowledged by the Panel. ${ }^{113}$ This understanding, however, is completely mistaken. Legally, whether a GATT provision can or cannot be applied to another agreement is a matter to be decided by the parties to that agreement, not the GATT. For instance, two countries that are not members of the WTO could agree to apply GATT rules in their bilateral trade relations; and the GATT (and its contracting parties) would have no say in such an agreement. Likewise, whether GATT Article XX can be applied to defend claims under the Accession Protocol is a matter of the intention of the parties to the Accession Protocol (i.e. the WTO and China). The task of the WTO judiciary is to ascertain such intention from the context of the Accession Protocol, not from the GATT provision itself. Hence, no issue of textual infidelity arises in this respect.

\section{III.A.ii. Interpretive flaws: an overlooked context in GATT}

65. The significance of its decision notwithstanding, the AB's reasoning suffers from some serious interpretive flaws. As explained below, these flaws appear to have stemmed from the failure of the $\mathrm{AB}$ to identify the GATT provisions on State trading as the relevant context for the trading rights provisions of the Accession Protocol.

\section{III.A.ii.a. A logical error}

66. The lynchpin of the AB's ruling is the introductory clause of paragraph 5.1 of the Accession Protocol, which states that China's trading rights commitments are "without prejudice to China's right to regulate trade in a manner consistent with the WTO Agreement". According to the AB, China's measures at issue can be WTO-consistent in one of two ways: (1) the measure is a type that the WTO Agreement recognizes that Members may take; or (2) the measure meets the condirions of a GATT exception, provided that it has "a clearly discernible, objective link" to the regulation of trade in goods. ${ }^{114}$ The $\mathrm{AB}$ did not explore the first possibility, focusing on the second instead. ${ }^{115}$ Upon finding "a clearly discernible, objective link" between China's measures and the regulation of trade in goods, the $A B$ concluded

112 The EU stated that Article XX(a) does not directly apply to China's Accession Protocol "because exceptions may be invoked only within the specific agreement in which they are contained, and accession protocol commitments are not part of the GATT 1994." AB Report, para. 111.

113 Panel Report, para.7.743 ("Article XX contains the phrase 'nothing in this Agreement', with the term 'Agreement' referring to the GATT 1994, not other agreements like the Accession Protocol.").

114 The AB Report, para.230.

115 The United States did not raise claims on trading rights under any WTO provisions other than the Accession Protocol. See AB Report, fn.433. 
that China is entitled to invoke a GATT exception to justify its measures in question.

67. There is, however, a problem in the AB's reasoning: China's measures at issue-the various requirements of State trading and import monopoly in the cultural sector-are, in fact, "a type that the WTO Agreement recognizes that Members may take", ${ }^{116}$ thus constituting the first way of being WTO-consistent as suggested by the AB. That is because the WTO Agreement does not prohibit State trading and import monopolies. As previously noted, liberalization of trading rights is a WTOplus obligation undertaken by a group of acceding Members only, and the scope of such obligation varies from country to country. Under the generally applicable WTO rules, Members remain free to establish and maintain State trading operations and import monopolies so long as they comply with the requirements set out in GATT Article II:4 (prohibiting monopolies from marking up prices for imports) and Article XVII (imposing certain disciplines on State trading enterprises). Furthermore, GATT Article XX(d) permits a Member's measure necessary for "the enforcement of monopolies" operated under Articles II:4 and XVII. ${ }^{17}$

68. Hence, it was erroneous for the Appellate Body to declare that China's measures at issue can be WTO-consistent either as a type permitted by the WTO Agreement or through an available exception. Because the trading rights commitments are WTO-plus obligations, that is, obligations more stringent than those prescribed by the generally applicable WTO rules, whether a measure in breach of such commitments may be deemed as WTO-consistent cannot be determined, as a matter of logic, by the generally applicable rules of the WTO Agreement. Simply put, a breach of a WTO-plus rule is not a breach of ordinary WTO rules. Therefore, the only way for the breach of a WTO-plus rule to be consistent with the WTO Agreement is through an available exception.

69. It should be noted that this logical error is also embedded in the text of the introductory clause of paragraph 5.1, which states that the trading rights commitments are "without prejudice to China's right to regulate trade in a manner consistent with the WTO Agreement". Since State trading monopolies are permitted under the GATT, China's right to maintain such monopolies is necessarily

116 Here, the AB clearly did not mean for "the WTO Agreement" to include China's Accession Protocol, which technically forms part of the WTO Agreement. For it would be circular to include the Protocol in the "WTO Agreement" in the interpretation of the introductory clause of paragraph 5.1 of the Protocol, which qualifies China's trading rights obligations by preserving China's right to regulate in a manner consistent with the "WTO Agreement".

117 A GATT panel clarified that Article XX(d) "permits measures necessary to enforce the exclusive possession of the trade by the monopoly, such as measures limiting private imports that would undermine the control of the trade by the monopoly," but "does not permit contracting parties to operate monopolies inconsistently with the other provisions of the General Agreement." Panel Report, Japan-Restrictions on Imports of Certain Agricultural Products, adopted 2 February 1988, GATT: Basic Instruments and Selected Documents (BISD) 35S/ 163, 230, para.5.2.2.3. See also GATT Analytical Index (1994), Article XX, paragraph (d). 
prejudiced by its trading rights commitments. ${ }^{118}$ However, even though the wording of the introductory clause is problematic, the $\mathrm{AB}$ could have avoided falling into the trap if it had identified the State-trading provisions of the GATT as the relevant context for the trading rights provisions of the Accession Protocol. The failure to recognize the relevance of GATT Articles II:4 and XVII in this context not only contributed to the logical error in the AB's reasoning, but also affected the $A B$ 's interpretation of the relationship between trade and traders under the WTO Agreement, which underscores its decision on both the applicability of GATT exceptions to the Accession Protocol and the necessity test under GATT Arricle XX.

\section{III.A.ii.b. The link between trade and traders}

70. According to the $A B$, in order for the GATT exceptions to be available to the trading rights provisions of the Accession Protocol, there must be "a clearly discernible, objective link" between China's measures at issue, which regulate traders, and its regulation of trade in goods. To ascertain whether such a link exists, the AB went to great lengths to establish the connections between trade and traders under WTO law. Firstly, it examined the relevant paragraphs of the Working Party Report elaborating China's trading rights commitments, which explicitly referred to the WTO requirements concerning import licensing, and the TBT and SPS agreements. ${ }^{119}$ Then, it observed that there is a "closely intertwined" relationship between China's trading rights obligations and the obligations of all WTO Members in respect of their regulation of trade in goods, and in particular, an "interlinkage" between China's trading rights obligations and GATT Articles III and XI. ${ }^{120}$ Next, it turned to GATT/WTO case law, citing a number of cases in which measures not directly regulating trade were nonetheless found to contravene GATT obligations, including restrictions imposed on investors, wholesalers and manufacturers. ${ }^{121}$ Upon further elaborations on how the link between the measure regulating traders and the regulation of trade can be discerned, the $A B$ concluded:

118 To avoid this problem, the introductory clause would have to exclude from its coverage the GATT provisions permitting State trading monopolies.

119 The Agreement on the Application of Sanitary and Phytosanitary Measures (SPS) and the Agreement on Technical Barriers to Trade (TBT). AB Report, paras.224-225.

120 In this regard, the $\mathrm{AB}$ cited paragraph 80 of the Working Party Report, which records certain Members' view that China's restrictions on trading rights were inconsistent with GATT Articles III and XI. Paragraph 80 was not incorporated into the Accession Protocol, hence is not legally binding. See $A B$ Report, para.226, fn.430. Interestingly, the AB cited this non-binding paragraph as reflecting the negotiating history of the trading rights commitments.

121 AB Report, para.227, fn. 432. 
Whether the necessary objective link exists in a specific case needs to be established through careful scrutiny of the nature, design, structure, and function of the measure, often in conjunction with an examination of the regulatory context within which it is situated. ${ }^{122}$

71. It is astonishing that the $\mathrm{AB}$ would go through such an elaborate route to find a connection between trade and traders under WTO law, while completely ignoring GATT Articles II:4, XVII and XX(d), which explicitly regulate traders owned or controlled by the State. From the very inception of the world trading system, the GATT contracting parties had recognized that State trading enterprises could be operated to "create serious obstacles to trade", and contemplated conducting mutually advantageous negotiations to limit or reduce such obstacles. ${ }^{123}$ Although commitments to reduce State trading operations have rarely been made in the multilateral trade negotiations, commitments to liberalize State trading have been sought from the acceding members of the WTO, especially the former State trading countries. ${ }^{124}$ In this sense, the trading rights commitments of China are part of a continuing effort of the Members to reduce potential barriers associated with State trading operations. Viewed in this systemic context, it should become crystal clear that there was no need for the Appellate Body to judicially establish the link between China's measures and regulation of trade. The link between trade and State-owned traders, the very subject in dispute, is firmly established by the GATT provisions.

72. The AB's failure to recognize the GATT State-trading provisions as the relevant context in this case is not without implications. By holding that the link between a measure regulating traders and the regulation of trade "needs to be established through careful scrutiny of the nature, design, structure, and function of the measure" in the specific case, the $A B$ has claimed the role of the final arbiter in determining the existence of such a linkage. In contrast, if the GATT provisions on State trading were recognized as the relevant context, the $A B$ would have to acknowledge the existence of such a linkage as dictated by the treaty language, rather than as a result of the exercise of its interpretive power. Put differently, the failure to recognize that the GATT provisions on State trading provide the relevant context for China's trading rights commitments has given the WTO judiciary more discretionary power in treaty interpretarion than warranted by the treaty text.

122 Id., para.230.

123 GATT Article XVII:3, and Interpretive Note to Paragraph 3 of Article XVII.

124 See Ernst-Ulrich Petersmann, GATT Law on State Trading Enterprises: Critical Evaluation of Article XVII and Proposals for Reform, in: Thomas Cottier and Petros C. Mavroidis (eds.), State Trading in the Twenty-First Century (University of Michigan Press, 1998), 71,85 . 
73. In addition, if the AB had identified GATT Articles II:4 and XVII as the relevant context, it could have established the applicability of GATT Article XX to China's trading rights obligations without having to rely exclusively on the illogical language of the introductory clause of paragraph 5.1 of the Accession Protocol. Viewed from a systemic perspective, Articles II: 4 and XVI provide the basic disciplines on State trading and import monopoly; and the trading rights commitments prescribe more stringent disciplines on State trading and import monopoly. If Article XX exceptions are available to the basic obligations under Article II:4 and XVII, there is no reason why the same exceptions should not be made available to the more stringent obligations on the same subject matter, unless the application of such exceptions would defeat the very purpose of the more stringent obligations or render such obligations meaningless. ${ }^{125}$

\section{III.B. The trader-based "necessity" test under GATT Article XX(a)}

\section{III.B.i. The trade versus trader dichotomy}

74. As previously noted, when applying the necessity test under GATT Article XX(a), the Panel added a separate "trader" factor to the existing interpretive formula. ${ }^{126}$ This addition is critical to the Panel's decision. Firstly, in the weighing and balancing process, it was the consideration of the measures' severe impact on potential traders, as opposed to their unclear impact on trade, that helped to tip the balance against China. Secondly, in deciding whether there is a reasonably available alternative, the Panel considered alternatives that would have less restrictive effect on importers, rather than on imports. Given the fact that the United States did not submit evidence showing the measures' restrictive impact on imports, it would have been very difficult to determine what might be a less trade-restrictive alternative.

75. To justify the addition of trader-based considerations, the Panel analogized the trading rights provisions of the Accession Protocol to GATT Article XI, which prohibits quantitative restrictions on imports. The Panel stated:

In our view, if Article XX is assumed to be a direct defence for measures in breach of trading rights commitments, it makes sense to consider how much these measures restrict the right to import. This would appear to parallel a situation where a member imposes a WTO-inconsistent ban on imports of products and where an Article XX defence requires examination of how much the ban restricts imports of those same products. Accordingly, we

125 It appears that the GATT Article XX(d) exception for domestic regulations relating to "the enforcement of monopolies operated under paragraph 4 of Article II and Article XVII" will be inappropriate for the trading rights obligations. Because the trading rights provisions generally prohibit import monopolies operated under Articles II:4 and XVII, the exception would render the trading rights obligations meaningless.

126 Above text to $\mathrm{nn} .36$ and 37. 
find it appropriate to consider two different types of restrictive impact in this case. $^{127}$ (Emphasis added.)

76. The Panel's reasoning was upheld on appeal. According to the Appellate Body:

The assessment of the restrictive effect to be taken into account in a particular dispute may, in appropriate cases, extend beyond an assessment of the restrictive effect on imported products, as this assessment must be undertaken in the light of the measure at issue, the specific obligation of the covered agreements that the measure infringes, and the defence being invoked. ${ }^{128}$

77. Thus, the WTO judiciary has created new jurisprudence under Article XX: when applied to trading rights obligations, the "necessity" test may include an assessment of the measure's restrictive effect on importers, as opposed to imported products. What has emerged from this reasoning, therefore, is a trade versus trader dichotomy under Article XX.

78. Notably, however, neither the Panel nor the $A B$ provided a clear rationale for their adoption of this trader-based effect test. The Panel simply stated that since Article XX was invoked to defend a breach of the trading rights commitments, "it makes sense" to consider how much the measures restricted the right to import. While the Panel also stated that it saw a parallel between the trading rights provisions of the Accession Protocol and GATT Article XI, it did not explain why such a parallel should be assumed to exist. On appeal, the $A B$ merely deferred to the Panel's finding by declaring that, "in appropriate cases", the assessment of the restrictive effect of the measures may extend beyond that on imported products.

79. It appears that, in seeing a parallel between the trading rights provisions and GATT Article XI, the WTO judges regarded the trading rights obligations as a new discipline of the WTO, instead of an extension of the GATT disciplines on State trading. Indeed, the trading rights provisions are qualitatively different from the GATT rules on State trading, as they prohibit State trading monopolies, rather than merely imposing conditions on them. This qualitative difference may well warrant a different effect test under Article XX. Given that the necessity test is a creation of GATT/WTO case law, adapting it to new situations would be well within the interpretive power of the WTO judiciary. ${ }^{129}$ However, as a matter of legal

127 Panel Report, para.7.788 (footnote omitted).

$128 \mathrm{AB}$ Report, para.306. For the same reason, the $\mathrm{AB}$ rejected China's appeal on the less traderrestrictive effect test. Id., paras.320-321.

129 The "necessity" test under Article XX was first articulated by the GATT panel in US-Section 337 of the Tariff Act of 1930, adopted 7 November 1989, BISD 36S/345. The test has continued to evolve under WTO case law, generating much literature on its jurisprudence. See, e.g., Jan Neumann and Elisabeth Turk, Necessity Revisited: Proportionality in World Trade 
reasoning, why a different effect test is warranted in this particular context needs to be explained. Unfortunately, neither the Panel nor the AB engaged in this level of analysis.

\section{III.B.i.a. The object and purpose of the trading rights obligations}

80. When Arricle XX is applied to defend measures in breach of the trading rights obligations, its interpretation should be made in the light of the object and purpose of such obligations. ${ }^{130}$ Although the Accession Prorocol does not articulate the rationale for the trading rights provisions explicitly, it is evident that such obligations were intended to compel China to reform its foreign trade regime. As noted above, at the time of its WTO accession, the Chinese government still controlled the allocation of trading rights. It was the subsequent implementation of the trading rights obligations that finally rid China of its State-trading regime. Once implemented, the trading rights obligations further prevent China from negating the reform. Unlike other Members, who remain free to adopt any trading system under international law, China cannot revert to a State-trading system or expand State trading activities beyond the scope of its trading rights commitments without incurring WTO consequences. In this sense, China has surrendered its sovereign right to choose or modify its foreign trade regime. ${ }^{131}$ It is fair to say, therefore, that the object and purpose of the trading rights obligations is to ensure that China adopts and maintains a market-based foreign trade regime. Such an object and purpose, however, need to be understood in the historical context of the trading rights obligations.

Organization Law after Korea-Beef, EC-Asbestos and EC-Sardines, 37 Journal of World Trade (2003), 199; Alan O. Sykes, The Least Restrictive Means, 70 University of Chicago LR (Winter 2003), 403; Donald H. Regan, The Meaning of "Necessary" in GATT Article XX and GATS Article XIV: The Myth of Cost-Benefit Balancing, 6 World Trade Review (2007), 347; Chad P. Bown and Joel P. Trachtman, Brazil-Measures Affecting Imports of Retreaded Tyres: A Balancing Act, 8 World Trade Review (2009), 85; Benn McGrady, Necessity Exceptions in WTO Law: Retreaded Tyres, Regulatory Purpose and Cumulative Regulatory Measures, 12 JIEL (2009), 153. For a latest critique, see Gisele Kapterian, A Critique of the WTO Jurisprudence on "Necessity", 59 ICLQ (2010), 89-127 (criticizing the necessity test, as currently applied by the WTO judiciary, as unsupported by the treaty text and overly intrusive into regulatory autonomy of the Members).

130 Although Article 31 of the VCLT refers to the "object and purpose" of a treaty as a whole, WTO adjudicators have routinely examined the "object and purpose" of particular treaty provisions. According to the $\mathrm{AB}$, Article 31 does not exclude taking into account the object and purpose of particular treaty terms, "if doing so assists the interpreter in determining the treaty's object and purpose as a whole." It also cautioned against considering the object and purpose of particular treaty terms in isolation from the object and purpose of the treaty on the whole. AB Report, EC-Chicken Cuts, paras.238-239.

131 For the Constiturional implications of such systemic commitments, see Julia Ya Qin, The Impact of WTO Accession on China's Legal System: Trade, Investment and Beyond, Wayne State University Law School Research Paper Series, No. 07-15 (papers.ssrn.com/ sol $3 /$ papers.cfm?abstract_id=985321). 
81. Historically, under the GATT, the world trading system did not require its members to be equipped with a market-based trading regime. Even though its rules were based on market economy assumptions, the GATT was supposed to be ideologically neutral to its members' choices of economic systems and to find ways to bridge the differences between them. ${ }^{132}$ Thus, the GATT recognizes the legitimacy of State trading and State import monopoly, while imposing certain conditions on their operations so as to prevent potential abuse. In order to accommodate a number of centrally planned economies joining the GATT, the trading system fashioned special rules, such as import commitments and special safeguards, when the regular GATT rules were considered inadequate to regulate the behaviour of fullscale State trading regimes. ${ }^{133}$

82. This approach changed after the end of the Cold War, when the communist regimes in the former Soviet bloc collapsed and most of the central-planning economies began to reform their systems according to market economy principles. ${ }^{134} \mathrm{By}$ the time the WTO was established, there were no longer two competing economic systems (planned versus marker), and economic ideologies had converged on the faith of free market. ${ }^{135}$ Hence, the former planned-economies became known as "transition economies", or countries "in the process of transformation from a centrally-planned into a market, free enterprise, economy". ${ }^{136}$ When these countries applied to join the WTO, the world trading system began to demand that they undertake the marketization of their economies. Liberalization of trading rights was one such undertaking. Armed with free market convictions, the WTO has also sought pro-market reforms including trading rights commitments from all orher acceding countries. ${ }^{137}$

83. This paradigm shift in the accession policy.coincided with the major expansion of the world trading system following the Uruguay Round. ${ }^{138}$ Concluded in 1993, the Uruguay Round agreements extended the reach of international trade regulation to many areas that were traditionally domestic regulatory domains, including trade in services, protection of intellectual property rights, investment, domestic subsidies and health and safety standards. Institutionally, with the

132 For an excellent description of this historical approach, see Chieh Huang, Non-Market Economies' Accession to the WTO: Evolution of the Approach and Implications for the Organization, 4 The Hague Journal of Diplomacy (2009), 61.

133 Id. For a detailed treatment of the subject, see Michel M. Kostecki, East-West Trade and the GATT System (New York: St Martin's, 1979).

134 See Huang, above n.132, at 72.

135 Id., 73-74.

136 SCM, art. 29.

137 See WTO Secretariat, above n.6. For example, Saudi Arabia undertook that, upon accession, it would grant the right to import to foreign firms and individuals with no commercial presence in Saudi Arabia, and to amend its laws to fulfil this commitment. Id., 36.

138 See Huang, above n.132, 72-73. 
establishment of the WTO, a more powerful dispure sertlement mechanism was put into place to ensure effective enforcement of WTO rules. This significant expansion in international governance inevitably reduces the domestic policy space of WTO members. ${ }^{139}$ Previously, under the GATT, the system was solely concerned with trade liberalization, and its interference with domestic regulation was limited essentially to the requirement of non-discrimination between imported products and domestically-produced like products. In contrast, the WTO has mandated certain international standards for domestic regulations, such as the standards for IP protection and health and rechnical regulations, which promote convergence of domestic governance norms irrespective of their effect on trade liberalization. Consequently, the WTO adjudicatory body is empowered to engage in more intrusive reviews and may strike down domestic regulations that do not conform to those standards even if they are not discriminatory or protectionist in design. ${ }^{140}$ Reflecting a deeper integration of the world economy, the expansion of WTO governance was also guided by the economic ideology of free market ${ }^{141}$ that propelled the paradigm shift in WTO's accession policy.

84. Of all the transition economies that have acceded to the WTO, China faced the most challenges in meeting the demands of the WTO. Unlike the East European countries, China never embraced a full-scale privatization of its economy and the Communist Party never lost control. Instead, the Party has led an economic reform that combines market mechanisms with government commands, and fosters private ownership while maintaining dominant State ownership in sectors deemed strategic to the nation. Given this "incomplete" conversion to the prototypical market economy, the WTO accession requirements on market-based reforms were more demanding for China to implement. Take the trading rights

139 Jeffrey Dunoff questioned whether WTO disciplines in each of the new areas are really about the potential restructuring of domestic regulatory and legal systems embedded in the institutional infrastructure of the economy. Jeffrey Dunoff, Lotus Eaters: Reflection on the Varietals Dispute, the SPS Agreement and WTO Dispute Resolution, in: George A. Bermann and Petros C. Mavroidis (eds.), Trade and Human Health and Safety (Cambridge University Press, 2006), 153, 173.

140 Two representative cases of this line decided under the SPS and the TBT, respectively, are: AB Report, EC-Measures concerning Meat and Meat Products (Hormones), WT/DS26/ AB/R; WT/DS48/AB/R, 16 January 1998; AB Report, EC-Trade Description of Sardines, WT/DS231/AB/R, 26 November 2002. See Henrik Horn and Joseph Weiler, European Communities-Trade Description of Sardines: Textualism and Its Discontent, in: Henrik Horn and Petros C. Mavroidis (eds.), The WTO Case Law of 2002 (Cambridge University Press 2005), 248, 251 (indicating the TBT and SPS standards represent as big a paradigm shift to international economic law as the prohibition on the use of force in the classical world of international law).

141 See Robert Howse and Kalypso Nicolaidis, Enhancing WTO Legitimacy: Constitutionalism or Global Subsidiarity? 16 Governance (2003), 73 (pointing out that the spirit in which the Uruguay Round rules were made reflected "over-enthusiasm for economic liberal ideology, not mere free trade, as the basic economic objective of the system."). 
commitments as an example. The East European countries merely needed to "confirm" that they already liberalized trading rights, ${ }^{142}$ whereas China had to make a major overhaul of its then-existing system. In this sense, China's undertakings are the most aggressive of all WTO obligations in terms of their effect on domestic policy and institution.

\section{III.B.i.b. The mission question}

85. Knowing that the purpose of the trading rights obligations is to ensure a marketbased trading system in China is not the end of the inquiry. A further question needs to be asked as to why such a system is desired by the WTO. Is it because a marketbased system is more conducive to achieving the goal of liberal trade, or is it because a market economy is in itself a value of the WTO? This is a question about the mission or the objective of the WTO. The answer to this question is key to understanding the implications of the trade versus trader dichotomy adopted by the WTO judiciary under Article XX.

86. Presumably, if one sees the reason for requiring market-based reforms in China as ultimately to promote free trade - the mission of the WTO as conventionally understood (the conventional trade model) —one will not find the need for a trader-based necessity test in the application of Article XX, since the ultimate purpose of the trading rights obligations is the same as that of the GATT obligations. Under this vision, the trading rights commitments would be understood as the extension of existing GATT disciplines on State trading. They were needed because the existing GATT rules were considered insufficient to address the issue of potential non-tariff barriers arising from the extensive State trading activities that remained in China at the time of its accession. Consistent with this view, the GATT general exceptions would be available to the trading rights obligations, just as they are available to the obligations prescribed by GATT Articles II:4 and XVII. ${ }^{143}$ In applying the general exceptions, the same necessity test under Article XX would be used, under which whether the measures at issue are protectionist in design and whether they have a major trade-restrictive effect would be important considerations. In this case, since China's measures are clearly maintained for political reasons and since no major trade-restrictive effect of the measures has been detected, the use of the conventional necessity test might well lead to the conclusion that China's measures could be excused by Article XX(a).

87. In contrast, if one views the reason for requiring systemic reforms in China as promoting free market as a value in itself, then one may perceive the WTO as having a different mission. Instead of being concerned with mere trade liberalization, the

142 See, e.g., trading rights commitments of Armenia, Kyrgyz Republic, Latvia, Estonia, Georgia, Albania, Croatia, Lithuania, Moldova and FYROM. WTO Secretariat, above n.6, 31-37.

143 Unless the application of the GATT exceptions would render the trading rights obligations meaningless, see above n.125. 
WTO is also concerned with setting "correct" norms for domestic economic governance, irrespective of the direct impact of such norms on international trade (the domestic governance model). Under this vision, the trading rights obligations would be understood as a separate discipline from the GATT disciplines on State trading, addressing concerns beyond State trading being potential non-tariff barriers. ${ }^{144}$ In accordance with this understanding, whether a measure violating the trading rights obligations can be excused by Article XX would not depend on the finding of protectionist intent and trade-restrictive effect. Rather, the legality of the measure would be examined against its impact on the systemic reform. To that end, the use of a trader-based necessity test would be warranted.

88. Although the Panel and the $\mathrm{AB}$ did not discuss the trading rights obligations by reference to the objectives of the WTO, their interpretation appears to reflect a vision that corresponds to the domestic governance model. Consistent with this model, they treated the trading rights obligations as a new discipline parallel to the discipline under GATT Article XI, rather than as an extension of GATT disciplines on State trading, and devised a trader-based necessity test for scrutinizing the measures under Article XX.

89. On the other hand, there appears to be an assumption underlying the Panel and $A B$ interpretations that restrictions on trading rights would necessarily have an adverse effect on trade. Thus, while acknowledging the fact that cultural imports into China had increased over time, the Panel also noted: "this increase did not necessarily indicate that China's measures had not had any trade-restrictive effect, because the statistics did not indicate what import levels might have been if the measures had not been imposed." 145 In endorsing the US proposal that the Chinese government conduct content review itself, the Panel stated that the US proposal would not result in any restriction on the right to import, and "would thus not produce any of the adverse effects on imports which the restriction of the right to trade would produce." 146 These statements seem to indicate that the Panel viewed the purpose of the trading rights obligations as ultimately to promote liberal trade, rather than pushing the reform agenda in China's domestic system, a vision that is consistent with the conventional trade model. Since neither the Panel nor the $\mathrm{AB}$ engaged in discussion on the object and purpose of the trading rights obligations and their connection to the objectives of the WTO, we are left in the dark as to the true rationale for the trader-based necessity test.

90. It should be noted, however, that the Panel's assumption that the restriction of the right to import would necessarily produce adverse effects on imports is

144 The fact that China agreed to grant trading rights to "all enterprises in China"-effectively privatizing all foreign trade activities except for a limited number of products--seems to support this understanding. See Accession Protocol, para.5.1; WPR, para.84(a).

145 AB Report, para.300 (summarizing the Panel's finding in this regard).

146 Panel Report, para.7.892. 
flawed. In theory, exclusive State trading may result in over-import as well as underimport, as compared to the import level set by a fully competitive marketplace. ${ }^{147}$ Over-import may occur if the State trading firms receive subsidies from the government or otherwise act according to government instructions. Given that China's State trading in cultural products is maintained for political reasons, liberalization would not necessarily lead to increased imports. Conversely, a restructured content review system as proposed by the WTO judiciary might well result in a reduced volume of imports as it could create an expanded bureaucracy and otherwise produce a chilling effect on imports. ${ }^{148}$

\section{III.B.i.c. Assessing the trader-restrictive effect under Article XX}

91. If we view the trading rights obligations as qualitatively different from GATT obligations, the WTO judiciary should have considerable discretion in fashioning new criteria under Article XX for assessing a measure's trader-restrictive effect. Depending on the chosen level of scrutiny, a treaty interpreter may assess the restrictive effect of the measure differently. For example, in the light of the object and purpose of the trading rights obligations, the treaty interpreter may consider it appropriate to examine the restrictive impact of the measures on China's foreign trade regime as a whole. Since China has liberalized trading rights in all sectors except the cultural sector, he may find that the measures do not have a significant impact on the systemic reform as intended by the trading rights obligations. Hence, when the trader-restrictive effect is assessed against the overall objective of the trading rights obligations, the result of the balancing under Article XX(a) could tilt in favour of China.

92. Alternatively, the treaty interpreter may choose to scrutinize China's measures more strictly, focusing on the measures' impact on the cultural sector exclusively. Since the measures have prevented liberalization of trading rights in the entire cultural sector, the treaty interpreter would find the trader-restrictive effect of the measures complete. This is effectively the approach taken by the Panel and the $A B$, even though it is unclear whether the judges were guided by the goal of deepening systemic reform in China. By taking this approach, the WTO judiciary assumed the role of arbiter in deciding what the proper scope of China's systemic reform should be.

\section{III.B.ii. The "less trader-restrictive" alternative}

93. With all the weighing and balancing, the ultimate test for "necessity" under Article XX has always been the less trade-restrictive means available. In the words of the Appellate Body, the result of weighing and balancing "must be confirmed

147 In practice, because of the lack of transparency in state trading operations, it may not be possible to know what import levels would be in a privatized trading market.

148 See Section II.C. 
by comparing the measure with possible alternatives, which may be less trade restrictive while providing an equivalent contribution to the achievement of the [measure's] objective." 149 The less trade-restrictive alternarive must be "reasonably available", but potential incurrence of higher administrative costs does not disqualify an alternative as a reasonably available one. ${ }^{150}$ In deciding whether such an alternative exists, the WTO judiciary has considerable discretion. Critics have observed that there is a potential danger of the test being used in a manner that compromises or rejects the Member's chosen level of protection. ${ }^{151}$

94. Adapting the test to trading rights, the Panel looked for alternatives that are less trader-restrictive. It found such an alternative in the US proposal that the Chinese government be given the sole responsibility for conducting content review. Since the government sets the review standards and has control over qualified reviewers, the Panel concluded that the proposed alternative would make "an equivalent or better contribution to the realization of the objective of protecting public morals", while having a significantly less restrictive impact on potential importers. $^{152}$

95. The logic of the Panel's reasoning seems impeccable. On appeal, China merely contested the reasonable availability of the proposed alternative, not its level of contribution to the stated objective. ${ }^{153}$ However, the Panel's reasoning did not take into account the desire of the Party to keep its censorship criteria secret and unpredictable. As previously explained, the secrecy and unpredictability of the censorship criteria provide the Party with a maximum degree of flexibility so that it can easily adjust them according to the perceived danger of the day. Should such a desire be considered a level of protection sought by the Chinese government? If so, then State trading, with its inherent opacity, is undoubtedly the most effective means to achieve that goal. In comparison, the proposed alternative, by allowing any number of private entities to become importers, could force the government to make the censorship criteria and process more transparent, thereby undermining the desired level of protection. But since China did not

149 AB Report, Brazil-Tyres, para.178.

150 An alternative may be found not to be "reasonably available" where it is merely theoretical in nature, or where it imposes an undue burden, such as "prohibitive costs or substantial technical difficulties", on the responding party. AB Report, para.310 (quoting AB Report, USGambling, para.308).

151 See Kapterian, above n.129, at 125-126 (pointing out that if a challenged measure is instrumental to the achievement of its goal, it is difficult to see how an alternative with less impact on trade could achieve the same level of protection sought by the Member).

152 Panel Report, para.7.899.

153 China argued that the proposed alternative would impose an undue financial and administrative burden on China. The $\mathrm{AB}$ was not persuaded, faulting China for failing to provide evidence "substantiating the likely nature or magnitude of the costs that would be associated with the proposed alternative, as compared to the current system". AB Report, para.328. 
make this argument (it would have been unseemly to advocate the need to maintain a non-transparent censorship regime), the Panel did not have to consider the unspoken rationale of China's measures. One wonders, however, whether all the parties involved in the WTO litigation were aware of this unspoken rationale. ${ }^{154}$

\section{III.C. Another overlooked treaty context: the Vietnam accession protocol}

96. Like China, Vietnam undertook to liberalize trading rights when it acceded to the WTO in 2007. ${ }^{155}$ Also like China, Vietnam had engaged in market-oriented economic reforms but maintained a significant State sector at the time of its accession. Unlike China, however, Vietnam explicitly excluded from its trading rights commitments the right to import certain cultural products. ${ }^{156}$ More significantly, "society morals" was identified as the rationale for such exclusion under the Vietnam accession protocol. ${ }^{157}$ Presumably, "society morals" is not a different concept from "public morals". ${ }^{158}$ Taken at face value, therefore, the Vietnam accession protocol recognizes the protection of society/public morals as the justification for State import monopoly in certain cultural products.

97. If this understanding is correct, then a potential inconsistency arises in WTO law. On the one hand, the WTO Agreement, of which both the China Accession Protocol and the Vietnam accession protocol form "an integral part", ${ }^{159}$ has accepted categorically that State import monopoly in cultural products can be

154 It is unclear to what extent China's litigation strategy and legal arguments were formulated by the foreign law firm representing China in this case, and whether the foreign lawyers involved understood the real rationale of China's measures. But if China had made the argument, the United States could probably have challenged the rationale under the transparency requirements of the WTO Agreement and the Accession Protocol. See above n.69.

155 Vietnam undertook that from the date of accession, all foreign firms and individuals would be able to engage in importation and exportation of products, except for the list of products reserved for exclusive state trading under Table $8(\mathrm{c})$. See Report of the Working Party on the Accession of Viet Nam, WT/ACC/VNM/48 (27 October 2006) ("Vietnam Working Party Report"), para.146, which was incorporated into the Protocol on the Accession of the Socialist Republic of Viet Nam, WT/ACC/VNM/48 (27 October 2006).

156 Such cultural products include: "Newspapers, journals and periodicals", covering subcategories of "scientific, technical or economic"; and "records, tapes and other recorded media for sound" covering cinematographic film, videotape and others. For products under each category, a state trading enterprise is designated as the sole importer and wholesale distributor. See Vietnam Working Party Report, para.72, and Tables 5 and 8(c).

157 Table 8(c) contains a column titled "Rationale", which sets out briefly the reason for each category of products reserved for exclusive state trading. The rationale column for the cultural products reads: "Cultural products affecting to [sic] society morals". Id. No further explanation provided.

158 Interestingly, the term "public morals" is used in Table 8(a) of the Vietnam Working Party Report, which sets out several categories of cultural products, including motion pictures and various printed matters, the state trading of which was to be liberalized by 1 January 2009 , and identifies the rationale for such delayed liberalization to be "sensitive to public morals".

159 Vietnam accession protocol, para. 2. 
justified by the reason of society morals; on the other, the WTO judiciary has held that, in the case of China, State import monopoly in cultural products cannot be justified by reason of public morals so long as there is a less trader-restrictive alrernative available. While the WTO dispute settlement decision is binding on the parties to the dispute only, the legal interpretation embodied in adopted panel and Appellate Body reports becomes "part and parcel of the acquis of the WTO dispute settlement system" and is expected to be followed in subsequent cases. ${ }^{160}$

98. One might argue that the two cases are totally different because Viernam negotiated a clear exception for State trading in cultural products, which became part of the bargain accepted by the WTO, whereas China failed to do so and merely attempted to justify its violation of the trading rights commitments post boc. ${ }^{161}$ It is true that if China had negotiated an explicit exception for cultural products during its accession, the United States probably would not have challenged China's measures in the first place. However, as a matter of WTO law, should the standard for the same policy exception to trading rights obligations vary depending on whether the exception is explicitly set out in the treaty text or is interpreted by the WTO judiciary? Or, if we are to assume there is a uniform standard, does it mean Vietnam's State import monopoly in cultural products is now open to challenge under the trader-based necessity test?

99. The issue raised here is again a systemic one: do one Member's accession commitments constitute a relevant treaty context for the purpose of interpreting the accession commitments of another Member? Formally, since all accession protocols have been made an integral part of the WTO Agreement, they constitute "context" for each other as part of the "text" of the same treaty under Article 31 of the VCLT. ${ }^{162}$ The question is whether they are "relevant" treaty contexts for each other. It is submitted here that the answer should be positive so long as the commitments at issue belong to the same category and reflect the same policy considerations. Take the trading rights commitments as an example. Although these commitments are country-specific, negotiated at different points in time and varying in scope and content, they fall under the same category of accession

160 AB Reporr, United States-Final Antidumping Measures on Stainless Steel from Mexico, WT/DS344/AB/R, adopred 20 May 2008, para.160. For reasons of ensuring "security and predictability" in the dispute settlement system, "absent cogent reasons, an adjudicatory body will resolve the same legal question in the same way in a subsequent case." Id.

161 It is unclear whether Vietnam explicitly excluded cultural products because it became aware of the issue from China's experience. The United States raised the issue of trading rights in China's cultural sector within the WTO in 2005, one year before Vietnam finalized its accession protocol. See WTO Transitional Review Mechanism Pursuant to Paragraph 18 of the Protocol on the Accession of the People's Republic of China, Questions from the United States to China, G/C/W/530 (12 October 2005).

162 Article 31(2) of the VCLT provides: "The context for the purpose of the interpretation of a treaty shall comprise, in addition to the text, including its preamble and annexes...". 
obligations sought by the WTO and share the same policy rationale. ${ }^{163}$ In this regard, the individual accession commitments are rather similar to the market access commitments under GATT and GATS schedules. Like the market access commitments, the accession commitments are made by one Member, but form an integral part of the WTO Agreement. It has been well settled under WTO law that with respect to one Member's schedule under GATT or GATS, other Members' schedules constitute relevant context for its interpretation. ${ }^{164}$ Accordingly, the accepted rationale for Vietnam's State import monopoly in cultural products should at least be consulted as part of a broader context for the interpretation of China's trading rights commitments under Article XX(a). In the event that the WTO judges wish to reject the relevance of the rationale in the Vietnam accession protocol, they should be expected to provide a reasoned explanation. Unfortunately, this issue has been completely overlooked.

\section{III.D. The issue of common intention}

100. It is well established that the purpose of treaty interpretation is "to ascertain the common intentions of the parties." 165 Given that the Accession Protocol is technically a bilateral agreement between China and the WTO, the task of the WTO judiciary in this case was to determine the common intention between China, on the one hand, and the WTO (on behalf of all other Members collectively), on the other. ${ }^{166}$ By definition, such "common" intention cannot be China's intention alone, but it cannot be without China's intention either. ${ }^{167}$ Put differently, absent China's intention, there would be no "common" intention to speak of with respect to its trading rights commitments.

163 See above text to nn.132-137.

164 See AB Report, EC-Chicken Cuts, para.193 (stating that the "broader context" of the term "salt" in the EC's schedule include other Members' goods schedules); AB Report, US-Gambling, para.182 (agreeing that other Members' schedules constitute relevant context for the interpretation of the US service schedule, with the caution that use of other Members' schedules must be tempered with the recognition that each schedule has its own intrinsic logic).

$165 \mathrm{AB}$ Report, European Communities-Customs Classification of Certain Computer Equipment, WT/DS62, 67, 68/AB/R, adopted 22 June 1998 (EC-Computer Equipment), para.84.

166 Conceptually, when the treaty is between China, on the one hand, and the WTO as an international organization, on the other, the intention of the WTO should be the collective intention of all WTO members excluding China. The bilateral character of the Accession Protocol, however, has never been discussed in WTO cases. See Qin, above n.7, 132-138.

167 Curiously, the $A B$ seems to have overlooked this basic point when it stated: "We further note that the purpose of treary interpretation under Articles 31 and 32 of the Vienna Convention is to ascertain the 'common intention' of the parties, not China's intention alone." $\mathrm{AB}$ Report, para.405. 
101. The common intention of the parties cannot be ascertained on the basis of "subjective and unilaterally determined" expectations of one party. ${ }^{168}$ Instead, it has to be identified objectively through proper application of the interpretive rules of the VCLT. $^{169}$ Under these rules, the text must be presumed to be an authentic expression of the intention of the parties. ${ }^{170}$ If the text, when read in its context and in the light of the object and purpose of the treaty, is ambiguous, recourse to extraneous evidence may be had, including the preparatory work of the treaty and the circumstances of its conclusion. ${ }^{171}$

102. It is clear that the Chinese government never intended to liberalize the right to import in the cultural sector. The absence of such intention can be readily observed from the consistency and firmness with which the relevant Chinese law and policy has been carried out throughout the era of economic reforms, and from the political rationale of such law and policy. It should come as no surprise, therefore, that the United States did not provide evidence suggesting that China had once contemplated liberalizing the right to import cultural products. Nor was there any indication that this particular aspect of the trading rights was ever discussed during China's accession negotiations. As noted above, China's neglect in excluding cultural products from its trading rights commitments explicitly can be explained by a mentality that took for granted the State control in the cultural sector. In execution, it was also attributable to the lack of experience and coordination among different government agencies that were in charge of approving the thousands of concessions China made during the accession negotiations. Hence, if the United States had actually held a different expectation from China's trading rights commitments, such an expectation would be just as "subjective and unilaterally determined" as China's expectation, and cannor serve as the basis for ascertaining the "common intention" between China and the WTO.

103. The issue of common intention concerning trading rights, however, was not discussed at all in the Panel and $A B$ reports. This contrasts sharply with the parts of the Panel and $A B$ reports dealing with GATS issues, in which the WTO judges examined the "common intention" behind China's commitment on "sound recording distribution services" (whether it was intended to cover electronic distribution) by going through each element of Articles 31 and 32 of the VCLT_ordinary meaning of words, context, object and purpose, preparatory work and the circumstances of the conclusion of the Accession Protocol, including China's domestic law

168 AB Report, EC-Computer Equipment, para.84.

169 Richard Gardiner, Treaty Interpretation (Oxford University Press, 2008), 6 (ascertainment of intention is one consequence of the excise if the Vienna rules are properly applied).

170 Id. (quoting the Commentary of the International Law Commission (ILC), which accompanied its draft articles for the 1968-1969 Vienna Conference at which the text of the VCLT was adopred).

171 VCLT arts. 31 and 32. 
and practice. ${ }^{172}$ In contrast, the WTO judges did not follow this interpretive format in their analyses of the trading rights provisions. While the text of the trading rights provisions and part of their treaty context was examined, their object and purpose was barely mentioned, and no reference was made to the preparatory work or the circumstances surrounding the conclusion of the Accession Protocol. ${ }^{173}$

104. It is unclear why the WTO judges pursued such different interpretive approaches in the two parts of the same reports. After all, both the trading rights commitments and the market access commitments under GATS are specific "concessions" made by China, and the issue in both contexts was the scope of the concession. If the text of the trading rights provisions were clear, there would be no need to resort to extraneous evidence to ascertain common intention. But the text of the trading rights provisions is not free from ambiguity-the introductory phrase of paragraph 5.1, which qualifies the scope of China's trading rights obligations, requires interpretation. Once the GATT general exceptions are read into the introductory phrase, the question becomes whether there was common intention among WTO members to permit possible exclusion of cultural products from trading rights commitments on the ground of protecting public morals. Judging from Vietnam's experience, such a common intention may well exist. ${ }^{174} \mathrm{Had}$ the issue been raised in this context, the parties might have had a chance to submit evidence showing the existence of the common intention, or the lack thereof, to liberalize trading rights in China's cultural sector. ${ }^{175}$

105. The fact remains that, despite the lack of "common intention" to liberalize trading rights in China's cultural sector, the WTO judiciary has concluded otherwise. This result raises a fundamental question in treaty interpretation: Why could the tension between "text" and "intent" not be resolved through the application of the VCLT rules? ${ }^{176}$ Is it because the VCLT rules are so rigid that their application necessarily dictated the disregard of the intent? Or is it because the rules were not applied properly? To better understand the issue, it would be helpful to consider these additional questions: (i) Is the text of the trading rights provisions so clear as to eliminate the need for recourse to supplemental means of

172 See Panel Report, paras.7.1172-7.1264 (of which paras.7.1244-7.1246 examined the circumstances of the conclusion of the Accession Protocol as reflected in China's domestic law and practice at the time); $A B$ Report, paras.348-411.

173 See Section III.E.i.

174 See Section III.C.

175 It is interesting to contemplate how such evidence might have affected the interpretation of Article XX(a), including its necessity test, since consideration of such evidence would not fit into the existing interpretive formula for Article XX.

176 In drafting the VCLT interpretive rules, the ILC considered three general approaches: (i) literal, (ii) teleological and (iii) intention. The ILC adopted a combination of the literal and teleological approaches, viewing application of these as yielding up the intention. Gardiner, above n.169, 8 . 
interpretarion, as instructed by Article 32 of the VCLT? (ii) If the text is not so clear, why was the recourse to supplemental means not made? (iii) If recourse to supplemental means should have been had, how should extraneous evidence, such as consistent China law and pracrice, and the historical background against which the Accession Protocol was negotiated, ${ }^{177}$ be considered in the context of applying Article $\mathrm{XX}(\mathrm{a})$ to the trading rights provisions?

106. Ultimately, treaty interpretation is an art, not science. ${ }^{178}$ In practising that art, the WTO judiciary should be able to apply the VCLT rules in a way that will reconcile any divergence between the treaty text and clear intentions of the parties, as ascertained objectively from the particular circumstances of each case. As the Appellate Body once declared:

The ordinary meaning of a treaty term must be ascertained according to the particular circumstances of each case. Importantly, the ordinary meaning of a treaty term must be seen in the light of the intention of the parties "as expressed in the words used by them against the light of the surrounding circumstances." ${ }^{79}$ (Emphasis added.)

107. The problem in this instance, however, is that no proper effort was made to identify such circumstances and to determine against the light of such circumstances whether the relevant common intention did exist.

\section{III.E. Identifying the sources of the interpretive problems}

\section{III.E.i. Deficiencies in the Accession Protocol}

108. In interpreting the WTO agreements, panels and the AB typically analyse the treaty text in question by examining each element of Articles 31 and 32 of the VCLT - firstly, the ordinary meaning of the treaty term, then the context and the object and purpose, and finally the supplementary means of interpretation. This interpretive format, however, cannot be easily applied in the context of the Accession Protocol. Unlike the WTO multilateral agreements, each of which contains a coherent set of generally applicable disciplines, the Accession Protocol prescribes China-specific rules that address subject matters across various WTO agreements. Yet, the Accession Protocol, which forms part of the WTO Agreement,

177 In the context of interpreting market access commitments under GATT schedules, the AB has construed "the circumstances" of the treaty's conclusion, as referred to in Article 32 of the VCLT, very broadly so they may include the historical background against which the treaty was negotiated, prior consistent practice of one party, unilateral acts and statements, subsequent practice of one party and domestic legislative acts and court decisions. See AB Report, EC-Computer Equipment, paras.86, 92-95; AB Report, EC-Chicken Cuts, paras.289, 305, 308-309.

178 Gardiner, above n.169, 5, 7.

179 AB Report, EC-Chicken Cuts, para.175 (quoting Lord McNair, The Law of Treaties (Oxford Clarendon Press, 1961), 365). 
does not always specify how the China-specific rules relate to the generally applicable WTO provisions. Consequently, it can be difficult to identify the relevant "context" of a particular provision of the Protocol. Furthermore, the Protocol does not provide explanations on why the many China-specific rules are needed, which makes it harder to identify the object and purpose of such provisions. ${ }^{180}$ While the overall purpose of the Accession Protocol is obviously to integrate China into the WTO system (or "allowing the WTO and China to establish, by mutual agreement, the terms under which China could accede to the WTO"181), this general objective sheds little light on the rationale of the specific Protocol provisions. In addition, the negotiation records for the Accession Protocol have not been made publicly available, depriving the treaty interpreter of a major supplementary means of interpretation.

109. The deficiencies in the Accession Protocol have left visible marks in the Panel and $A B$ reports. As noted above, the WTO judges did not follow the normal interpretive format in their interpretation of the trading rights provisions. After discussing the ordinary meaning of the treaty terms, the Panel and the AB did nor go through all the elements constituting the "context" as defined by the VCLT. And there was no mention of the object and purpose of the trading rights provisions; nor was there any reference to the supplementary means of interpretation, such as the preparatory work and the circumstances of the Protocol's conclusion. Once the discussion moved to the section dealing with GATS issues, in contrast, the Panel and the AB resumed their usual format of interpretation. One can find subsections in the GATS part of the reports clearly labelled by each element of Articles 31 and 32 of the VCLT. ${ }^{182}$

110. This change in the interpretive format is not merely a matter of style. Rather, it reflects the difficulties the WTO judges encountered with a strict textualist approach to treaty interpretation. Given the deficiencies of the Accession Protocol, to interpret the Protocol provisions properly in accordance with the VCLT principles would require the judges to develop a truly "holistic" approach-an approach that would place the text of the Protocol in its broad historical and systemic contexts. The $\mathrm{AB}$ has made a significant move in this direction by making GATT Article XX available to the trading rights obligations. But that move is still constrained. In the final analysis, it is the failure to interpret China's trading rights obligations in their historical and systemic contexts that prevented the $A B$ from recognizing the connection between the trading rights obligations and the GATT disciplines on State trading. And it is the same failure that prevented the $A B$ from appreciating the WTO-plus nature of the trading rights obligations, causing

180 Above n. 130.

181 Panel Report, para.7.281. The AB report made no mention of the object and purpose of the Protocol.

182 See the Table of Contents in the Panel Report and AB Report, respectively. 
it to misstate the ways in which China's measures can achieve consistency with WTO law.

111. The trading rights commitments are just one of the many China-specific obligations imposed by the Accession Protocol. More WTO-plus and WTOminus provisions of the Accession Protocol have entered the pipeline of the dispute settlement process. ${ }^{183}$ How to interpret these provisions coherently and consistently within the WTO treaty framework poses a major challenge to the panels and the AB. While it might be prudent to decide each case on narrow grounds, it would be a mistake, as a matter of WTO judicial policy, to view each of the China-specific provisions in isolation, rather than in the light of the historical context in which the Accession Protocol was negotiated.

\section{III.E.ii. The challenge of systemic commitments}

112. The trading rights commitments are broad systemic undertakings that have introduced a fundamental reform of China's foreign trade regime - a reform that has essentially privatized all foreign trade activities in China except for a few areas deemed vital to the State's interests. Commitments at this systemic level are unprecedented in the history of the world trade regime. At issue in this case is China's policy of keeping the cultural sector off-limits to such reform. The reason for this exclusion is political: State trading in the cultural sector ensures that the Party can rely on trusted SOEs to carry out its arbitrary and capricious censorship criteria in a non-transparent manner. Meanwhile, the trade effect of this policy is unclear. Thus, by bringing this case to the WTO, the United States was effectively asking the WTO judiciary to determine what the proper scope of China's systemic reform should be, and how the Communist Party should run its censorship regime with respect to imports. Never before had the world trade tribunal engaged in the scrutiny of domestic governance at such a deep level.

113. The basic question facing the Panel and the $A B$ was this: does China's policy limiting the scope of its economic reform for political reasons fall within the legitimate policy space of China, or the jurisdictional competence of the WTO? Put in terms of standards of review, the question was whether the WTO judiciary should give more deference to China or apply strict scrutiny when reviewing such policy. ${ }^{184}$

183 See, e.g., China-Measures related to the Exportation of Various Raw Materials (DS394, DS395, DS398) (involving China's WTO-plus obligation to eliminate all export taxes); United States-Measures Affecting the Imports of Certain Passenger Vehicle and Light Truck Tires from China (DS399) (involving WTO-minus China-specific safeguard rules); and the two cases China has brought against the EU involving "WTO-minus" China-specific rules on antidumping measures (DS397, DS405).

184 The concept of appropriate levels of scrutiny is often used interchangeably with the concept of standards of review, which in the WTO context refers to the degree of deference the WTO adjudicatory body should give to the national authority's factual and legal determinations. For a comprehensive treatment of the subject, see Matthias Oesch, Standards of Review in WTO Dispute Resolution (Oxford University Press, 2003). See also Stefan Zleptnig, The 
Clearly, the Panel and the AB chose strict scrutiny. Thus, instead of relying on the traditional trade-based necessity test under GATT Article XX, the judges created a trader-based test, focusing on the measures' impact on potential traders in cultural products rather than on China's foreign trade regime as a whole. ${ }^{185}$ The adoption of the test and the way in which the test was applied ensured that China's policy would not pass the scrutiny.

114. The problem with this result is not so much about the level of scrutiny applied, although that is definitely a concern, but the absence of any articulated rationale in support of the chosen level of scrutiny. For a decision that invalidates a Member's policy of such political nature, the WTO judiciary owes to the Member and the institution of the WTO a policy-based explanation. Yet, throughout the Panel and $\mathrm{AB}$ reports, one cannot find any discussion on what China's trading rights obligations are intended to achieve and how those obligations are supposed to contribute to the objectives of the WTO. Some teleological discussion would have been necessary to explain why strict scrutiny of China's policy under Article XX was warranted. ${ }^{186}$

115. The lack of policy-level discussion in the Panel and $A B$ reports is not new. There has been a tendency at the $\mathrm{AB}$ to limit its legal reasoning to textual analysis, rather than discussing the treaty terms in their broader systemic context and in the light of their "object and purpose", which would entail inquiries into the underlying policy considerations. ${ }^{187}$ Critics have described the $A B$ 's approach as one of "textual fetishism and policy phobia". ${ }^{188}$

116. It is particularly unfortunate that the "policy phobia" should manifest so clearly in the interpretation of the Accession Protocol in this case. Being the first WTO dispute over a major Member-specific obligation (outside GATT and GATS schedules), the trading rights controversy invited the WTO judiciary to set out an analytical framework for addressing the special interpretive issues arising from such obligations in a systematic manner. Instead of taking up the opportunity to do so, the WTO judges chose to avoid the systemic issues altogether. The only

Standard of Review in WTO Law: An Analysis of Law, Legitimacy and the Distribution of Legal and Political Authority, 6 European Integration online Papers (2002), No. 17 (eiop.or. at/eiop/texte/2002-017a.htm).

185 See Section III.B.i.c.

186 See Section III.B.i.a. and III.B.i.b.

187 As a former $A B$ member noted, the discussion of object and purpose "does not sit well with strict constructionism" since it leads to teleological interpretation. See George Abi-Saab, The Appellate Body and Treaty Interpretation, in: Giorgio Sacerdoti, Alan Yanovich and Jan Bohanes (eds.), The WTO at Ten: The Contribution of the Dispute Settlement System (Cambridge University Press, 2006), 453, at 462. But not all AB decisions are in the same strand. See Horn and Weiler, above n.140, at 252 (pointing out that "when it appears fit the $A B$ is no less teleological, contextual, or systemic than any other tribunal of similar standing").

188 Irwin and Weiler, above n.86. 
place in their reports touching upon the systemic dimension of the issues is a statement by the Panel that "we must be mindful of the possibility that the Accession Protocol may impose obligations on China that are not imposed on other Members under the WTO Agreement, or are stricter than those that are applicable to other Members." ${ }^{189}$ The point of this statement was not to explain why such stricter obligations were imposed on China, but to opine that the stricter obligations should not necessarily prejudice China's ability to regulate trade. ${ }^{190}$ As for the $A B$, it did not acknowledge the phenomenon of Member-specific obligations at all, let alone discussing the issues arising therefrom. Apparently, the unwillingness of the $A B$ to inquire into the rationale of the China-specific trading rights obligations not only caused it to be oblivious to the parts of the treaty context that are systemically most relevant to such obligations, but also rendered it unable to provide a rationale for the adoption of the trader-based necessity test.

117. The reason why the WTO judiciary shunned policy-level discussions might be to avoid criticism of "judicial activism" and to ensure the legitimacy of its decisions. Yet, in failing to articulate the rationale for such a far-reaching decision, the WTO judiciary paradoxically engaged in policy making in a most active fashion. The narrow textualist approach taken by the WTO judiciary cannot help but undermine the legitimacy of its decision. As Horn and Weiler keenly observed:

There is an appreciable difference in the legitimacy of a decision where the decisor is seen to have recognized fully the context (understood here in its broad sense) of the text under interpretation and which is seen to inform its decision whatever the outcome, and a decision in which the decisor seems oblivious to the context of its decision. Likewise, and no less importantly, there is a difference between a decision which is seen to be aware of its consequences, and is seen to have made its hermeneutic choices in full awareness of such consequences. When the Vienna Convention speaks of interpretation in the light of object and purpose it simply invites a consequentialist approach. Jurists' prudence is usually a recipe for good jurisprudence, but it is not to be confused with narrow textualism. ${ }^{191}$

118. Regrettably, the Panel and the $A B$ in this case did not demonstrate that they recognized the systemic context of the trading rights obligations or were fully aware

189 Panel Report, para.7.281 (emphasis added).

190 Id.

191 Horn and Weiler, above n. 140 , at 253. They further observed that there is a major difference in interpretive approach between the International Court of Justice (ICJ) and the AB: in contrast with "the unwillingness of the $A B$ to siruate its legal analyses within a framework which firmly articulates both the normative and policy considerations and consequences of its decisions", the ICJ is willing "to go much further in this respect", as evidenced by most of its cases in the last 20 years. Id. 
of the political ramifications of their decision. There was no indication that they ever pondered the question of whether China should be given more deference on a matter that defines the scope of its domestic economic reform. In the end, it is unclear whether the Panel and the AB intended by their strict scrutiny to push systemic reforms in China, hence consciously embracing a new model of WTO governance, or merely acted out of their gut feelings without fully realizing the consequences at stake.

\section{III.E.iii. Other factors}

119. The lack of a systemic perspective on the issues raised by China's trading rights obligations is not just the problem with the WTO judges alone. The reasoning of the Panel and the $\mathrm{AB}$ was shaped to a large extent by the arguments of the disputants. And the ability of the parties to appreciate the systemic dimension of the issues may have been affected by the insufficient attention paid to the Member-specific obligations in the field of WTO study.

\section{III.E.iii.a. China's defence}

120. As the defendant in this case, it was incumbent upon China to present the policy rationale of its measures and explain to the judges what was at stake. However, instead of framing the issues at a systemic level, China mostly reacted to the arguments made by the United States. Hence, China did not present its view as to what its trading rights commitments were intended to accomplish (i.e. the object and purpose of the trading rights provisions) and why maintaining State trading in the cultural sector did not interfere with the overall transformation of China's foreign trade regime. Arguments anchored in the broad systemic context of the trading rights commitments might have helped the judges to better understand the consequences of their decision and compelled them to articulate the policy considerations underlying the outcome.

121. China's defence was likely constrained by political and institutional factors. The government might not want to present its trading rights defence at a systemic level lest such an approach highlight the fact that China is subject to major systemic obligations not undertaken by other Members. Because China is politically sensitive about its WTO-plus obligations and does not wish its WTO membership to be perceived as different from or "inferior" to that of others, ${ }^{192}$ it would rather downplay the significance of such special obligations. At a more concrete level, China did not raise the issue of common intention. Evidence, such as pre-accession discussions within the government concerning trading rights in the cultural sector, and official

192 It was observed that in the Doha Round negotiations "China's ultimate goal is to be like everyone else. China therefore resents some of the terms imposed as part of their WTO accession, apparently some think as much as they resented the nineteenth century unequal treaties." Robert Wolfe, Sprinting during a Marathon: Why the WTO Ministerial Failed in July 2008, 44 Journal of World Trade (2010), 81, 114. 
documents showing consistency in relevant law and policy, could have been presented to demonstrate China's lack of intention to liberalize trading rights in the cultural sector. ${ }^{193}$ However, to defend its case in those terms would have implied an admission of China's missteps in the accession negotiations, which would not be palatable to the government. Furthermore, China's lawyers would not have been free to explain the true rationale of the measures at issue-the desire of the Party to maintain a non-transparent censorship regime.

\section{II.E.iii.b. Insufficient attention to WTO member-specific rules}

122. There has not been sufficient attention paid to the systemic issues raised by the Member-specific rules of the Accession Protocol. Of the large number of works on China and the WTO, only a few articles have focused on these issues. ${ }^{194}$ Major English textbooks on WTO law, for example, rarely mention the existence of China-specific obligations, let alone discuss their legal and policy implications. ${ }^{195}$ Given the importance of China's accession for the WTO system, it is puzzling why most mainstream authors have chosen to ignore the issues. One can only surmise that the lack of attention in the literature did not help the WTO judges and litigants to become better informed.

\section{Conclusion}

123. China-Publications is a landmark case in international law. Among other things, the decision requires China to restructure its censorship regime governing the importation of cultural products. The required restructuring, while not intended to affect censorship criteria substantively, threatens to deprive the Communist Party of its most efficient means to achieve the level of protection desired by the regime. Inherently non-transparent, the operation of State trading enterprises enables the

193 Unilateral acts and statements may be accepted as evidence of "the circumstances" of the treaty's conclusion under Article 32 of the VCLT. Above n. 177.

194 Meanwhile, the problem of political imbalance between the applicant country and the collecrive incumbent membership in WTO accession negotiations has received more attention. See, e.g., Kent Jones, The Political Economy of WTO Accession: The Unfinished Business of Universal Membership, 8 World Trade Review (2009), 279, 310 (pointing out that heavyhanded treatment of the applicant in accession talks "may poison the well of future trade negotiations").

195 Of the nine recent English textbooks on WTO law examined by the author, only one briefly mentions that the terms of China's accession "go beyond the letter" of WTO obligations and "are widely seen as unfair by the Chinese." Michael J. Trebilcock and Robert Howse, The Regulation of International Trade (3rd edn., Routledge, 2005), 641. In addicion, one book lists the major terms of China's accession (Raj Bhala, International Trade Law (3rd edn., LexisNexis, 2008)), and another recognizes the existence of WTO-plus and WTOminus provisions for the acceding Members in general (Petros C. Mavroidis, George A. Bermann and Mark Wu, The Law of the World Trade Organization (West, 2010)). None of the books provides further analysis. 
Party to keep its censorship criteria confidential, thereby preserving a maximum degree of flexibility and control. By telling the Chinese government to reconstruct its censorship machine-a matter at the core of its political system-the WTO decision has pushed global governance to its contemporary limits.

124. The most remarkable aspect of the decision is this: the WTO judiciary held China's measures to be WTO-illegal, despite its recognition that the measures were taken for political rather than protectionist reasons and that the trade effect of the measure was uncertain. In essence, the WTO has demanded that China abandon State trading as the means to achieve its censorship objective, and adopt instead a censorship mechanism that is considered more suitable for a privatized trading regime. In other words, China should become more like most other countries in the administration of censorship (in the sense that State trading is not used as a tool to achieve censorship objectives in most other countries). This decision, therefore, is the latest and perhaps most salient indication that the world trading system has moved beyond its traditional governance model solely concerned with economic protectionism, towards a new model that mandates convergence in domestic governance norms.

125. To comply with the WTO decision would require China to engage in serious reforms of its domestic system. Abolishing State monopoly in cultural imports would dismantle one of the bastions of China's State-owned economy, resulting in further privatization of the cultural sector. More critically, the government would need to redesign its censorship system to accommodate a potentially very large number of private importers. When numerous domestic and foreign entities are allowed to participate, the system must be prepared to provide a basic level of transparency and due process, which, however, would threaten to undermine the efficacy of the Party's rule.

126. Ironically, if China were to follow the WTO proposal and establish a new censorship bureau to perform content review independent of importers, the result might well be greater restrictions on the importation of cultural products. That is because under the current system, the SOE importers enjoy a great deal of discretion in applying censorship criteria and have financial incentives to maximize imports; in contrast, content reviewers solely responsible to the censorship bureau would be motivated to screen imports as rigorously and strictly as possible.

127. Given the enormity of the stakes, it is not surprising that China has thus far failed to fully implement the WTO decision. While a few more steps might be taken towards compliance, complete liberalization of trading rights is unlikely to occur in the current political climate. The poor prospect for full compliance highlights the peril when the WTO attempts to regulate measures that are ultimately political rather than economic in nature.

128. The Appellate Body in this case has broken new ground in W'TO jurisprudence. It held for the first time that GATT general exceptions can be made available 
as defence for the breach of another treaty under the WTO Agreement. In so holding, the Appellate Body took a giant step towards making the enormously complex treaty structure of the WTO internally coherent.

129. However, the $\mathrm{AB}$ decision on trading rights is ultimately problematic for the following reasons. Firstly, its legal analysis contains serious flaws. Most strikingly, the AB completely overlooked the GATT provisions on State trading as the relevant textual context for the trading rights provisions. Consequently, it misstated the way in which China's measures may become WTO-consistent, and erroneously declared a judicial standard for identifying the linkage between trade and traders on a caseby-case basis when such a linkage is manifest in the text of GATT provisions. Secondly, in the application of Article XX(a), the AB endorsed the trader-based necessity test invented by the Panel without proper reasoning. Given the unclear trade effect of China's measures, the invention of the trader-based test was critical in enabling the Panel to invalidate the measures under Article XX(a). Yet, for such a key element in the decision, neither the Panel nor the $A B$ provided any meaningful analysis as to why the new test was warranted. Thirdly, the decision was made with little regard to its consequences. The judges understood very well that the challenged measures were taken for political reasons and that requiring China to restructure its censorship regime would be a highly politically sensitive matter. Nonetheless, they chose to apply strict scrutiny to invalidate the measures, relying on a proposed alternative censorship mechanism that they considered to be reasonably available to China but without a real understanding of, or concern for, its potential political repercussions. Moreover, for such a far-reaching decision, the judges failed to articulate any normative or policy rationale in support, which cannot help but undermine the legitimacy of the decision.

130. The problems identified above are attributable to the special difficulties of interpreting Member-specific rules within the WTO multilateral treaty framework. But they ultimately expose the fatal weakness of the narrow textualist approach taken by the WTO judiciary. The trading rights obligations involved in this case are systemic commitments undertaken by China to transform its foreign trade regime into a market-based one. The basic question confronting the Panel and the $A B$, therefore, was whether China should be allowed to exclude the cultural sector from the scope of its systemic reform for political reasons. In arriving at the negative answer to this question, the judges did not discuss what the trading rights obligations are intended to accomplish, how these obligations relate to the WTO objectives and what effect the challenged measures have had on the reform intended by these obligations. In other words, in determining whether China's measures can be excused by Article XX(a), the judges failed to interpret the Arricle XX(a) exception in the light of the object and purpose of the trading rights provisions and of the WTO Agreement, as is required by the interpretive rules of the VCLT. Evidently, the unwillingness of the judges to inquire into such object and purpose prevented 
them from appreciating the historical and systemic contexts of the trading rights provisions. As a result, they were unable to identify the textual contexts that are systemically most relevant to the trading rights provisions, or to articulate a normative or policy rationale to support their chosen level of scrutiny under Article XX(a). In the end, what the public received is a far-reaching WTO decision ostensibly built upon a literal construction of the "ordinary meaning" of the words.

131. When all is said and done, there is a basic lesson to be learned. The WTO is not designed to regulate the domestic political systems of its members. Pushing the limits of WTO governance beyond what it is designed to do risks creating more non-compliance cases, ultimately undermining the effectiveness of the WTO system. 